Portland State University

PDXScholar

\title{
A Study of the Willingness of Elderly People to Live With Each Other
}

Joanne Welander

Portland State University

Marvin Clifford

Portland State University

Follow this and additional works at: https://pdxscholar.library.pdx.edu/open_access_etds

Part of the Demography, Population, and Ecology Commons, and the Social Psychology and Interaction Commons

Let us know how access to this document benefits you.

\section{Recommended Citation}

Welander, Joanne and Clifford, Marvin, "A Study of the Willingness of Elderly People to Live With Each Other" (1971). Dissertations and Theses. Paper 1563.

https://doi.org/10.15760/etd.1561

This Thesis is brought to you for free and open access. It has been accepted for inclusion in Dissertations and Theses by an authorized administrator of PDXScholar. Please contact us if we can make this document more accessible: pdxscholar@pdx.edu. 


\section{AN ABSTRACT OF THE THESIS OF Marvin Clifford and JoAnn}

Welander for the Masters Degree of Social Work presented May 15, 1971.

Title: A Study of the Willingness of Elderly People to Live With Each Other.

\section{APPROVED BY MEMBERS OF THE THESIS COMMITTEE:}
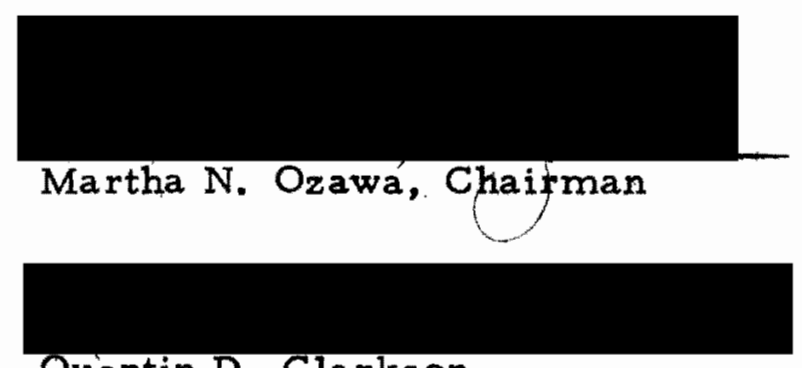

Quentin D. Clarkson

This research project was focused on elderly people and their

living arrangements in an attempt to discover whether elderly people would prefer to live alone or with other elderly persons. If it was found that the elderly people interviewed would like roommates, then this would provide information which would be helpful in assessing the need for and determining the feasibility of a roommate service for elderly people.

Willingness to roommate served as the dependent variable. This 
study tested the relationship between each of two psychological variables, loneliness and independence, and the dependent variable. Loneliness was defined $a_{s}$ an elderly person's feeling of being alone, and independence as an elderly person's ability to do things unaided. In addition, twelve demographic variables were used to describe the sample: sex, age, marital status, separation time, health, religion, length of time living in Portland, length of time living alone, income, education, occupation, and number of activities. The data obtained from these variables enabled the researchers to answer the following questions :

1. What are the characteristics of the sample?

2. What are the relationships of loneliness and independence to willingness to roommate?

3. What are the correlations between each of the demographic and psychological variables and the dependent variable?

The population consisted of all those elderly people 62 years of age and over who lived alone in Portland Public Housing as of May 15, 1970. The sample was composed of 220 people from this population who were selected by choosing every sixth name from a list of 1,699 names. Letters were sent in two different mailings, and of the sixtyfour who responded, fifty-six were interviewed.

The student researchers collected the data by using the structured interview. The data was coded, programmed and pracessed through 
an IBM 1130 computer.

The data analysis indicates that independence is correlated with willingness to a higher degree than any other single variable. Loneliness is negatively correlated with willingness, but the correlation is so small it is not meaningful. An analysis of the data reveals the sample to be mostly White, Christian, female, healthy and highly independent. As a group they are not lonely and not willing to roommate; these people prefer privacy and living alone. They are not really willing to share their bathrooms, furniture or rent; however, they may be willing to help another homeless elderly person by allowing that person to stay temporarily. It was concluded that the people in the sample do not feel that they need roommates; therefore, a roommate service probably is not feasible for this group of people.

Since the population studied in this project was characterized by a high level of independence, future research will be necessary to determine if a less independent population would be more willing to roommate. 


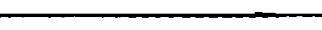


A STUDY OF THE WILLINGNESS OF EIDERLY PEOPLE

TO LIVE WITH EACH OTHER

\author{
by \\ JOANN WELANDER \\ and \\ MAR VIN CLIFFORD
}

\begin{abstract}
A thesis submitted in partial fulfillment of the requirements for the degree of
\end{abstract}

MASTER OF SOCIAL WORK

Portland State University

1971 
TO THE OFFICE OF GRADUATE ST UDIES:

The members of the Committee approve the thesis of JoAnn Welander and Marvin Clifford presented May 15, 1971.

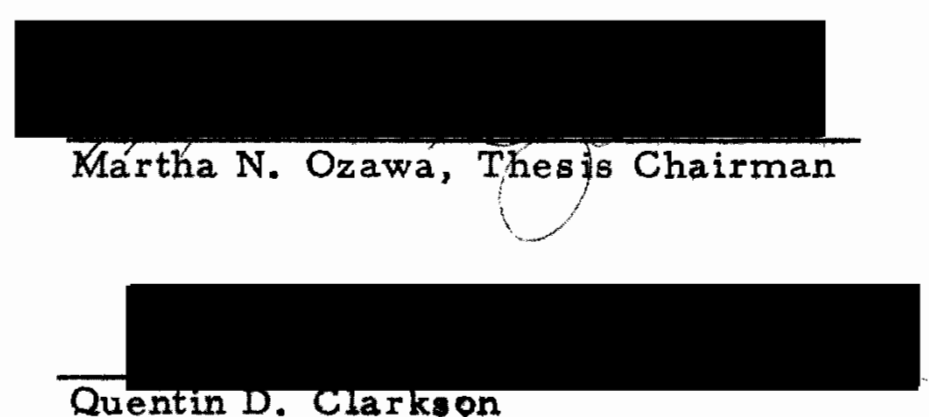

Quentin Clarkson

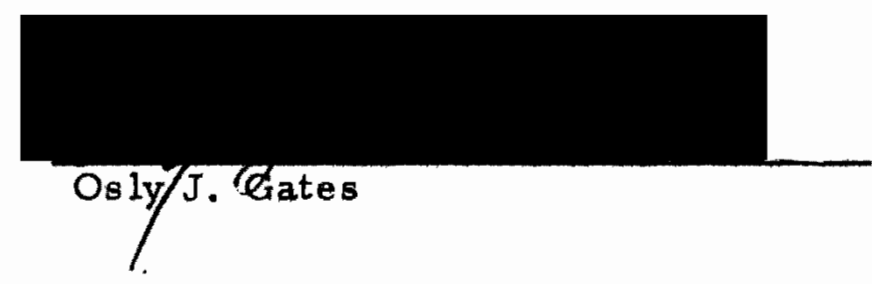

\section{APPROVED:}

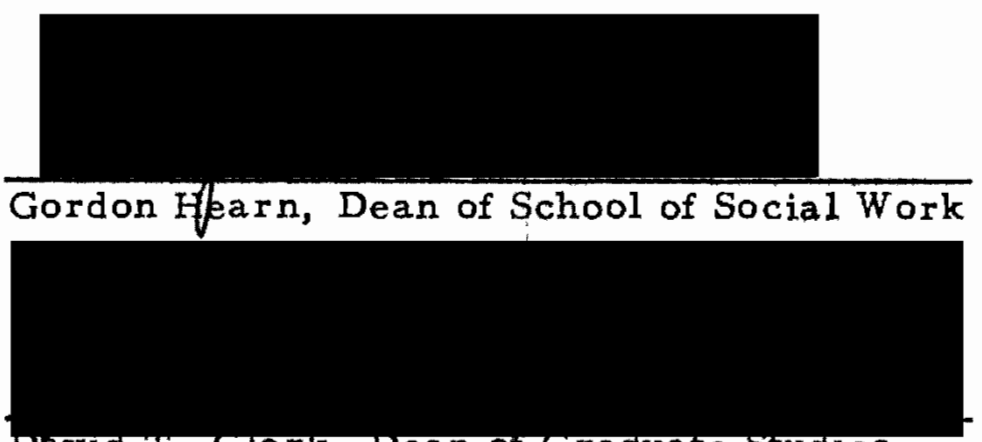

Drvid 1. Clark, Dean of Graduate Studies

May 15, 1971 


\section{ACKNOW LEDGMENTS}

We are deeply indebted to many interested people for their encouragement, direction and assistance in the development of this thesis.

We are especially grateful to:

Dr. Martha N. Ozawa, whose guidance and support was invaluable in assisting us through all the phases of this study.

Osly J. Gates, Director of The City-County Council on Aging, and Mrs. Patty Zilka, Social Worker at the Council on Aging, who shared their knowledge of and enthusiasm for the elderly, and the use of their agency.

Ray Rowe, who was instrumental in obtaining the sample.

Dr. Quentin D. Clarkson, with whom we consulted on all matters concerning methodology and analysis.

Mrs. Marion $R$. Hughes was instrumental in providing under Title III of the Older American's Act, School of Social Work, Portland State University; a research grant to investigate the feasibility of a roommate service for the elderly. This thesis is a report of two student's contributions to the research project directed by Dr. Martha N. Ozawa. 
TABLE OF CONTENTS

PAGE

ACKNOW LEDGMENTS iii

LIST OF TABLES vi

CHAPTER

I INTRODUCTION AND REVIEW

OF THE IITERAT URE 1

Research Focus 2

Significance of the Aged

as a Research Topic 3

Housing:- It's Significance for the Elderly 5

Alternative Living Arrangements 6

Advantages of Roommating 8

Limitions $\quad 13$

$\begin{array}{ll}\text { Summary } & 15\end{array}$

$\begin{array}{ll}\text { II METHODOLOGY } & 16\end{array}$

$\begin{array}{ll}\text { Type of Research } & 16\end{array}$

$\begin{array}{ll}\text { Discussion Groups } & 16\end{array}$

$\begin{array}{ll}\text { Population } & 18\end{array}$

Sampling Plan 20

Construction of Questionnaire 22

Pretests and Precautions 24 
$\begin{array}{ll}\text { Scoring Technique } & 25\end{array}$

$\begin{array}{ll}\text { Research Design } & 27\end{array}$

III COLIECTION AND ANALYSIS OF DATA 32

Collection of Data $\quad 32$

Sample Description $\quad 34$

Correlations Between Each of the Independent Variables and Willingness to Roommate

Simple Correlations $\quad 43$

Analysis of Willingness to Roommate Question 46

IV DISCUSSION, CONCLUSIONS, IIMITATIONS AND RECOMMENDATIONS

$\begin{array}{ll}\text { Discussion } & 50\end{array}$

$\begin{array}{ll}\text { Conclusions } & 58\end{array}$

Limitations of the Findings $\quad 59$

$\begin{array}{ll}\text { Recommendations } & 61\end{array}$

$\begin{array}{ll}\text { Summary } & 64\end{array}$

BIB LIOGRAPHY $\quad 65$

$\begin{array}{lll}\text { Appendix A Introductory Letters } & 75\end{array}$

$\begin{array}{lll}\text { Appendix B } & \text { Questionnaire } & 78\end{array}$

$\begin{array}{lll}\text { Appendix C Answer Sheet } & 90\end{array}$

Appendix D Iegend for Scoring 92

$\begin{array}{lll}\text { Appendix E Scoring Changes } & 98\end{array}$

Appendix F Simple Intercorrelations Matrix 99 


\section{LIST OF TABIES}

TAB LE

PAGE

I Reliability Test Results

II Range of Scores

III Research Model

Simple Correlations

IV Research Model

Partial Cor relation: Independence and Willingness to Roommate

V Research Model

Partial Correlation: Loneliness and Willingness to Roommate

VI Research Model

Simple Intercorrelations Matrix

VII Number of Respondents According to Each Health Category

VIII Number of Respondents According to Income, Race and Religion

IX Number of Respondents in Each Occupational Category

$\mathrm{X}$ Number of Respondents Retired and Reasons for

Retiring

XI Means, Standard Deviations, and Correlation Coefficients of Variables Correlated with Willing ness

XII Multiple Correlations of Loneliness, Independence, and Demographic Variables to Willingness to Roommate 
XIII Means, Standard Deviations, and Possible Ranges of Independence, Loneliness and Willingness

XIV Meaningful Correlations of Variables

XV Respondent's Answers to Willingness to Roommate Questions

XVI Simple Intercorrelations Matrix 


\section{CHAPTER I}

\section{INTRODUCTION AND REVIEW OF THE LITERATURE}

Although the aged population has increased by $600 \%$ while the rest of the U. S. population has only increased by $250 \%$ since 1900 (May, 1965, p. 89), we feel that relatively little has been done either to better understand this swiftly growing generation or to serve their needs. The developments in scientific technology which have helped to greatly lengthen the life span of so many people have also pirated from them the dignity and feeling of work that were once synonymous with age. The development of the United States from an agricultural to an industrial economy has not only affected employment, but has also changed the structure of the family. As a result, the role of the elderly in the family and the community has changed. How can the dignity and feeling of worth that is necessary to a proud and meaningful aging be restored? This is the underlying question that has motivated and guided this particular study of the aged people in Portland, Oregon.

In this report are included the wealth of fascinating experiences, revealing insights and objective data which have each been important components of this research study. This study explores the possibility of having elderly people who are presently living alone, live or room 
with another elderly person. This, of course, is not a completely new idea; there are some elderly people who are presently living in pairs. At the present time, public housing in Portland is not available to elderly people of the same sex who live in pairs. Requests for elderly companions can be found regularly in the want ads section of the newspaper. The City-County Council on Aging in Portland has several requests each day from elderly people who no longer want to live alone. Yet, there is apparently no city-wide program through which an elderly person could contact a social worker, or any other type of person in whom he could place his trust, if he needed assistance in finding a suitable roommate. As a result these researchers decided to interview the elderly people themselves to learn if they desire such a service and, if so, to discover any common characteristics among those who are interested in having a roommate.

\section{RESEARCH FOCUS}

This research is focused on three main variables. The dependent variable has been entitled "an elderly person's willingness to roommate", that is, a person's predisposition to living in the same household with another elderly pers on of the same sex who has been chosen on the basis of compatibility by a third party, such as a social worker. There are two independent variables, the first of which is "an elderly person's degree of independence", which has been defined as the 
intensity of a person's perception of his ability to do things without the aid of others. The second independent variable has been designated as, "an elderly person's degree of lonelines s", which has been defined as the intensity of a person's feeling of being alone.

Each of these variables has been defined in a limited and operational form for the purposes of this study. There is, therefore, no claim to measure the broad psychological variables of independence or loneliness, but rather the overt components of independence and loneliness, as they are seen to be significant to elderly people generally, and to the aspects of this study specifically.

This study is an exploratory research study, the purpose of which is to learn the relationship between the dependent variable of willingness to roommate and the independent psychological variables of degree of loneliness and degree of independence. Through the use of certain sociological variables, the sample will be described and the posaibility will be investigated of any common characteristics which might differentiate those who are willing to roommate from those who are not willing. This study will also investigate the possibility of any correlation between each of the sociological variables and the psychological variables. Therefore, each of the sociological variables has also been used as an independent variable for the purposes of analysis. 


\section{SIGNIFICANCE OF THE AGED AS A RESEARCH TOPIC}

We feel that a study, such as ours, of the aged population is an important and significant area for research. A review of the literature has proven to us that relatively little research has been done to better understand the elderly, their needs and their desires. In fact, very little data based on hard research in connection with the aged was found. In general, most of the literature consisted of the authors' beliefs and opinions. Yet, the elderly make up a significant proportion of our population. According to the 1970 census (U. S. Dept. of Commerce, a, 1971), there are $29,665,776$ people 60 years and older in the United States, or $14 \%$ of the total population. About $65 \%$ of the aged people live alone (Modern Maturity, October-November, 1968 , p. 56). Statistics for 1970 show that 77,502 people 60 years of age and older live in Portland; this is $20 \%$ of the total Portland population (U. S. Dept. of Commerce, b, 1971).

The insufficient scope of research and services for the aged indicate the presence of many unmet needs among the aged. The literature discusses these needs in great detail: it appears to be the norm for elderly persons to have a meager income, to live in inadequate housing, to suffer from poor health, and to feel alone and isolated. This seems to justify the conclusion that not only is our society basically youth oriented, but so too is the majority of available services. 
Margaret Blenker, in her paper entitled, "The Normal Dependencies of Aging" (1968) states that,

With the sole exception of Medicare we have made little or no progress in the United States in the last decade towards realistic societal solutions on a mass basis to problems that arise out of the normal to be expected dependence of aging.

\section{HOUSING: ITS SIGNIFICANCE FOR THE ELDER LY}

Because housing has an immense effect on the total life situation of elderly people, this study has been limited to specific aspects of housing. Francis Carp (1967) discusses the results of a study which illustrated that elderly people who move from substandard housing, or a condition of social isolation or interpersonal stress, to improved life settings in a public housing facility show impressive results not only in terms of increased satisfaction with their living situation, but also in more favorable attitudes about themselves and towards others, improved physical and mental health, and in more sociable patterns of life. If moving to a new building can so positively and broadly affect one's life, it would seem logical to conclude that the effects of living with someone after having lived alone would be even greater. Surely the interacting, the sharing, caring and giving of one to another would have as great an effect as moving to a new building.

The alternative housing arrangements available to the elderly seem to be quite limited. These include institutionalization, living 
with relatives, living alone or living with someone. The Institute on the Rehabilitation of the aging (1960, pp. 9-36) speaks of "enormous amounts of money being spent on the institutionalization of many people who obviously should not be hospitalized." This Institute also explains that the design of institutions allows for regression and depression rather than for some kind of restitutional process. It identifies "the need of our aging population for a continuation of productive socially responsible, personally satisfying behavior until the end of the life cycle."

\section{AITERNATIVE IIVING ARRANGEMENTS}

Institutionalization is not meeting this need for many who are unnecessarily living in such settings. "To the older person, the institution symbolizes the end of mastery over his fate as well as a turning away of society from him--a mutual withdrawal (Riley, 1968, p. 577). Roger Olsen (1971) of the Portland Community Council, is studying the community system of screening recommendations received for the committment of elderly people to the state hospital. Mr. Olsen believes roommating to be a possible means of preventing mental deterioration in older adults since isolation from social and sensory stimulus has been found to be a significant factor in mental deterioration. $\mathrm{Mr}$. Olsen feels that placing elderly people in a situation in which frequent 
interaction occurs may be a means of preventing some institutional commitments.

In the literature we found frequent reference to "living with relatives" as an alternative to institutionalization. According to a study done by Townsend (1963) regarding the family living arrangements of older people in the United States, of those who are divorced, widowed, or single, approximately $49 \%$ are living with relatives. Although almost half of the people in this group live with relatives, this has been proven to be a very unsatisfactory situation for many.

Randall (1944, p. 57) gives an example of a widow who was living with her daughter. This woman felt that no one knew her for herself, she was always someone's grandmother or aunt. She felt that if she lived with people her own age, she could regain her self identity. Belcher (1967, p. 536) believes that "many relatives take in the oldsters only because they feel it is their duty." The tone and feelings which would develop in a home where this duty were being performed certainly wo uld not be conducive to a very satisfying existence.

A number of authors seem to agree that living with relatives can be very detrimental. For example, O'Dell (1966, p. 49) states that:

Sometimes the best solution to the loners problems may seem to be in living with other members of his family. . This solves some problems, but usually creates new ones. The loss of independence may make the feeling of loneliness even worse. A better solution for the person who has tried living alone and doesn't like it is to find someone of his own age and circumstances with whom to share his living quarters. 
Not only is living with relatives unsatisfactory for many who have tried it but for others it is not even an alternative from which they may choose, because as they have no relatives with whom to reside (Randall, 1944, p. 61).

\section{ADVANTAGES OF ROOMMATING}

After reviewing the lite rature, a conclusion has been drawn by these writers that there are many advantages to roommating other than its being an alternative to institutionalization or living with relatives. For example, of the many problems and unmet needs of the elderly, inadequate income is one of the most glaring. Statistics accentuate the bleak financial picture for the unmarried (who often live alone).

While at least $20 \%$ of all married couples had incomes below the 1967 poverty threshold developed by the Social Security Administration, at least $50 \%^{1}$ of all non-married persons had incomes below this line (Bixby, 1970, p. 8). "More than $40 \%$ of the older persons living alone or with non-relatives had incomes of less than $\$ 1,500$ in 1968

\footnotetext{
${ }^{1}$ We say at least $20 \%$ and at least $50 \%$ because these percentages are based on income levels below the poverty line. The income of married couples is based on $\$ 1,999$ while the poverty line is $\$ 2,020$ and the income of all non-married persons is based on $\$ 1,499$ while the pove rty line is $\$ 1,600$. See Mollie Orshansky, "Counting the Poor" and "Who's Who Among the Poor", Social Security Bulletin, January and July, 1965; for recent revisions see the Bureau of the Census, Current Population Reports: Consumer Income, Series P-60, No. 68.
} 
(U. S. Dept. of Health, Education and Welfare, 1970, p. 10)." Through the sharing of rent and grocery bills, these expenses could be greatly reduced so that a meager annual income of $\$ 1,000 \mathrm{might}$ be more adequate. For example, an apartment for two costs much less than two separate apartments, food bought in larger quantities is more economical, and there is less waste and spoilage of food if there are two people to eat it. To further illustrate that two elderly people can live more inexpensively together than alone, the "poverty line" as determined by the U. S. Department of Agriculture is utilized. According to this standard, the poverty level is set at $\$ 1,920$ for one person and at $\$ 2,460$ for a couple. This standard assumes that two people living alone require a total of $\$ 3,840$ or $\$ 1,480$ more than two people living together as a couple (United States Congress, House, 1970, p. 62). The literature also cites increased nutritional level as an advantage of having elderly people live with someone. Both nutritionists and social scientists alike believe that companionship influences the digestive processes. One author (Aging, October-November, 1969, p. 12) gives an example of a woman who was living alone. Although this woman's diet was adequate, her metabolism test showed a lack of nutrients. When her grandson came and stayed with her, her diet did not change, yet she was able to utilize the nutrients. Possibly companionship and sharing of meals played a vital role in maintaining her nutrition. The emotional stress of the elderly is also related to 
isolation and loneliness as a cause of malnutrition. It is known that depression can cause a loss of appetite and interest in proper food nutrition. Other authors, such as Lang (1961), Hazell (1965), Robert Oyler (1968) and Francis Carp (May, 1969) also discuss the relationship between health and companionship which attests to the popularity of this hypothesis.

It is agreed by most authors that many of those who live alone, without the companionship of others are lonely. Joast (December, 1958, pp. 3811-812) feels that loneliness is limitless for the aged and that if analyzed from the human and psychological point of view, it is the biggest problem they face. The President's Council on Aging (1964, p. 63) defines virtual isolation and aloneness as severe stress for older people. In the book, Social and Medical Problems of the Elderly (1965, p. 208) Hazell reports on the scope of the affect of loneliness on the lives of the elderly.

Continued loneliness brings about not only mental illness in the way of apathy, indifference, depression or even demenția, but also physical illness resulting from lack of reasonable exercise, inattention to diet with poor nutrition, and failure to obtain treatment for any accompanying illness. The physical illhealth worsens the mental state and visa versa, so setting up a vicious circle of poor general health.

The literature also supports our belief that living alone fosters loneliness. Tunstall in his book, Old and Alone (1966, p. 88) explains that, "Old people who live alone are also much more likely than those who live with others to be lonely." He describes the recently 
widowed as most likely to feel lonely and alone.

Rather than allowing this cycle of loneliness and poor physical and mental health to continue, steps should be taken to fulfill the elderly person's need for social contact. Dorothy Larson (1966, p. 54) emphasizes the need to prevent the loss of communication. Robert Oyler (1968) has found that even in elderly people with good health, the disengagement from social relationships seems to be associated with diminishing morale. In a study made by Cornell University, Marilyn Langford (1962, p. 2) explains that:

The need for belongingness and love may require the evolution of new social and affectional relationships as mates die, children leave home, and lifelong friends die or move away.

One step which may be taken to enhance an elderly person's feeling of belongingness is to offer him the option of choosing a roommate as a substitute for the deceased spouse and grown children who have left the elderly person. Thus through the use of roommates, one of the major problems of elderly people--loneliness--may be appreciably decreased.

Elderly people also have a vital need to retain a feeling of independence. Dorothy Larson (p. 24-25) discusses the extent of this need, concluding that elderly people need their independence more than anything else. They need a continued sense of responsibility for themselves; if responsibility is removed too soon, aging may accelerate, because this will remove the basic factors which are necessary 
for the individual's ego strength.

Brickfield (February-March, 1968, p. 39) describes the ideal

espoused by the U. S. Department of Health, Education and Welfare.

The American ideal of old age is that of the sturdily independent and self-sufficient individual who is reasonably happy and healthy, and who has a secure place in the affections and lives of relatives and neighbors.

It seems that such an ideal is not without adequate foundation since only five percent of aged Americans live in institutions and perhaps another five percent remain bedridden at home. Brine (1970, p. 5) discusses Frances Carp's belief that it is better to fight age than to accept it since "acceptance of old age holds out few if any rewards". Housing and independence are very closely linked since it is believed that an older person's continued independence is influenced by how he settles his question of housing (President's Council on Aging, (1964, p. 113). Tunstall (1966, p. 55) believes that many of those who live alone do so as a last attempt to retain their independence. After having lost a major portion of their independence to poor health and inadequate income, such symbols of domestic autonomy as having their own door key or their own kitchen are aspects which elderly people refer to as proof of their surviving independence. For many, this dying independence is almost completely eradicated by institutionalization or living with relatives. The concept of roommates is suggested as a much more preferable option. In this way, elderly people may 
retain the sense of self responsibility they so strongly desire.

\section{IIMITATIONS}

Through reading the descriptions of aging as viewed by numerous authors, the researchers became aware of some common beliefs about elderly people which might hinder the wide use of roommates. For instance, the President's Council on Aging (1964, p. 113) believes that,

People, as we've seen resist change especially as they grow old, and one can say that this human trait is accentuated when dealing with housing.

The results of a Cornell University research program on housing for the aged, led Marilyn Langford (p. 31) to conclude that:

Although no large scale studies of either preferences or effects of change on the aged or their communities have been made, people tend to agree that the aged have a strong desire to remain in the home of their middle years, even though they may be alone and have physical and financial difficulty in maintaining it.

The attitude of elderly people about living with someone might prove a further barrier to their acceptance of roommates. In a study conducted in Lond on by Jeremy Tunstall (1966, p. 55) the overwhelming majority of elderly who were interviewed said they preferred to live alone; only $9.4 \%$ said they would rather live with others. The trend in the United States might be quite similar since research conducted in the small U. S. community of Northwood revealed that of the seventy aged persons interviewed, "71 percent felt living alone was the best way" (Rose and Peterson, 1965, p. 188). 
For some elderly people the value placed upon individual freedom and self determination will be so great that it will overshadow any need for close social relationships. Privacy, too, is of paramount importance to many elderly people.

A common deterent . . restraining some persons from living with older aged peers is the fear of too much pressure or too little privacy (Sherman, et al, 1968, p. 170).

In a paper delivered at the Institute on Rehabilitation of the Aging, Victor Howery (1960, p. 79) states that the elderly person:

seem to be able to withstand the vigor of interaction for a limited period of time only. . . he needs privacy as a device for rejuvenation.

Some authorities believe that the degree of satisfaction found in a particular living arrangement is not so much dependent upon the type of living arrangement nor whether a pers on lives alone or with a roommate. These authors feel that the degree of satisfaction is a function of the social activity and life style of the particular person. In other words these people believe that whether or not an elderly individual has a roommate, is not as important as his social contacts with others. One further limitation of our research study as it has been organized, is the fact that a verbal commitment does not necessarily mean actual behavioral commitment. Since this is an attitudinal study, further research may be necessary to see whether a person who says he would or wo uld not like a roommate would actually follow through on his expressed desire. 
VII. SUMMARY

Before proceeding to the next chapter on methodology, it would be useful to briefly summarize what has been presented thus far. The growth in the aged population has been noted and compared to the lack of research and services related to this age group. Through reviewing the literature it has been found that housing is very important to the elderly. Consequently, the alternatives of institutionalization, living with relatives, independent living, and living with a roommate have been analyzed. It has been suggested that living with a roommate would (1) reduce the cost of living, (2) increase one's nutritional level, (3) retard one's feeling of loneliness and (4) retain a sense of independence for many aged people. Yet, because some elderly people tend to resist change, prefer to live alone and desire privacy, many elderly people may oppose the idea of having a roommate.

We do not claim to have a perfect study; we only hope to help the readers to develop an interest in the human feelings and needs of the elderly population.

Through this research, we hope to learn if elderly people are willing to roommate; and we hope to discover some of the factors influencing an elderly person's degree of willingness, to roommate. 

CHAPTER II

METHODOIOGY

In this chapter, the methodology of this research project will be discussed, including an explanation of the type of research study, the population and sampling plan used, the construction of the questionnaire, and the scoring technique.

\section{TYPE OF RESEARCH}

Reviewing the literature made these writers are aware of the lack of research conducted in relation to aging. As a result an explanatory study was formulated in order to better understand the elderly. Because our original interest was simply to learn more about the aged, our original methods consisted of reviewing the pertinent literature and talking with people who have worked with the aged. We soon recognized the need for a new concept in housing for the elderly, and therefore we limited our study to the discussion of a roommate service, keeping the research design flexible.

\section{DISCUSSION GROUPS}

Initially, we formed two discussion groups for elderly people. Each of the two student researchers formed a group of eight elderly 
men and women who met for nine, one and one half hour weekly sessions. One group met at the Taft Hotel, where all of the members lived; the other group met at the Council on Aging. Many of the group members lived solely on Social Security and/or Public Assistance.

Both groups spent a great deal of time talking about the Hippie sub-culture, the economy and other current topics. Initially we viewed this digression as resistance to talking about one's self and one's problems, but we later realized that such discussion may be necessary for the elderly to express their fear and confusion in regard to their role in today's society. We began to see such discussion as projection of their feelings of anxiety, anomie and isolation.

Other topics discussed in the groups included services for the elderly, housing information, loneliness, senescence, health problems and feelings about these topics. Each member seemed to take pride in his independence, no matter how humble his existence. The elderly spoke of loneliness with more anxiety then when they spoke of death. One woman said she always felt like she was "on the outside looking in." When asked if they would like to live with a roommate, group members were unable to give a definite answer and only spoke about concepts like freedom, patience, and individual differences in relation to living with someone.

Through these weekly sessions we gained an understanding of the elderly which greatly assisted us in constructing our questionnaire. 
We are indebted to these people for helping us to understand aging, the views of the elderly, and their attempts at survival in a world which they see as rapidly changing.

\section{POPULATION}

Our population was originally defined as all ambulatory people, 60 and over, living alone in Portland. Through the use of this broad population we hoped the results of this study would become a significant contribution to a better understanding of Portland's elderly, and a motivating force to city-wide program development.

Although we explored numerous sampling alternatives, we found most of them extremely unsatisfactory. We first attempted to draw a stratified random sample of the population in which all socio-economic levels would be represented. We had hoped to gain the cooperation of the Social Security Administration in allowing us to use the names of all Portland residents 62 and over. Since Federal law protects the confidentiality of such files, we were unable to use them.

Mr. Gates, Director of the Council on Aging, also offered us the names of people served by his agency (about 5,000 elderly people). Since this population consisted of a unique type of person we felt that findings from a study of these people could not be applied generally to elderly Portland residents and therefore would not be very useful in understanding the elderly of Portland, nor in implementing any new programs for them. 
Marion Hughes, Director of the Oregon State Programs on Aging, advised us of a Medicare Alert canvas of Portland made in 1965 by Friendly House. Although Friendly House still had a file of all the people contacted during this alert, there were several disadvantages of using this listing. The alert was conducted five years ago, and many of the people had moved or died since then. Also, the youngest pers on in that population would be 70 years old now, the reby eliminating.representation of all 60-70 year old people.

At this point, few choices were left. Criteria could be set up for canvasing various retirement complexes and apartment buildings, but such an accidental sampling would not yield definite information which could validly be applied to the general population. We had considered limiting the population to members of certain church groups or other easily accessible organizations, but again, this would be selectively limiting our population. According to an article in the February, 1970, issue of Geriatric Focus, this would limit the population to those who were not in great need of services.

It is frequently observed that when community services are provided for the aged, those persons in the greatest need of such services are the least likely to take advantage of them. . . The more alienated they feel, the less use they make of services provided by that society.

After facing the various sampling difficulties mentioned above, we revised our population to include only those elderly people 62 and over who live alone in Portland Public Housing. This population was 
made available to us through Ray Rowe of the Housing Authority of Portland. Although it only represents the working class and poor aged, we feel that this population is appropriate for the purposes of our study since almost $30 \%$ of the aged population is poor. We feel that this group is representative of the proportion of elderly people, who are most in need of public services.

In summary, we chose our population on the basis of availability, representation of the most needy, and suitability for program development, if so indicated.

\section{SAMPLING PLAN}

The sample was selected from a computerized listing of all Housing Authority of Portland (HAP) residents, 62 and over, effective May 15, 1970. This list consisted of the names of 1,699 residents of both conventional and leased housing. The names were grouped according to housing project or leased housing unit and alphabetized. Every sixth name was selected for systematic sample. It is a reasonable certainty that this sample is representative of the population and that the data relating to the variables of interest is randomly distributed in the sample.

This process resulted in a list of the names of 282 elderly HAP residents. For 60 of these names, no addresses could be found, either due to their having moved or their desire to remain somewhat anonymous. 
Although we were aware that 172 elderly people from the original list of 1,699 were living with others, our source of information did not differentiate those living alone, from those who lived with others. In order to compensate for this fact, we decided to delete the questionnaire when talking with these people and to disregard any of their comments when tabulating the data.

One of the stipulations to which we agreed in order to interview these HAP residents, necessitated the sending of letters to each of the HAP residents whom we wished to interview, requesting their permission to conduct this interview. We realize this was a great disadvantage since it further defined the type of respondent we would get, yet we also realized the necessity of such an agreement. Letters were sent to 220 elderly HAP residents. After a six week period, only 40 elderly people responded, accepting our request to be interviewed. We sent a second letter to all but those who had been interviewed. An additional 24 responded. Of these 64 responses, eight could not be used either because they were not living along or because they were not at home. ${ }^{1}$ Fifty-six interviews were conducted.

Since many of these people did not have phones we could not make exact appointments. Response cards included with the letters sent, asked respondents to check the most convenient times for the interview. If, after three attempts, respondent could not be reached at home, no further attempts were made. Copies of the letters can be found in the Appendix. 


\section{CONSTRUCTION OF QUESTIONNAIRE}

The primary means of data collection consisted of a structured interview in which a 77 point questionnaire was used. The two student researchers conducted all interviews.

We found many advantages to the use of this method. The questionnaire provided uniformity and standardized answers which were kept in a frame of reference easily accessible to analysis. By administering the questionnaire ourselves we were able to interpret questions for the respondents and guard against misunderstanding. We feel this is an absolute necessity when working with the aged since many cannot read nor fully understand what is expected of them in such a situation.

Although the questionnaire consisted of fixed alternative responses, we kept the interview flexible so that the elderly could freely express their opinions and feelings. The interviewer would then classify the information, asking for clarification if necessary. Through the use of the structured interview we could also observe the aged and his situation.

Because we were unable to find a simple standarized measure of the variables of our study, we designed our own. ${ }^{2}$ Questions 1-26

${ }^{2}$ References used in the construction of the questionnaire included: Jeremy Tunstall, (1966) Susanne Reichard, et al (1962); Delbert Miller, (1967, U. S. Dept. of Health, Education and Welfare's Guide 
measure "degree of ability to do things unaided" (independence), questions 27-44 measure "feeling of being alone" (loneliness), and questions 45-59 measure "willingness to roommate." The majority of these questions were indirect or inferred (for example, rather than ask a person if he feels lonely or experiences anomie, we asked if he feels others enjoy his company). Since the purpose of our questions were somewhat camouflaged we hoped that more honest responses would be given. Questions 60-77 measure the sociological variables of sex, age, marital status, history, length of time separated from spouse, health, religion, race, length of residence alone, length of residence in Portland, income, education, occupation, anddegree of social activity.

Before using this questionnaire, we met with Dr. Ozawa, our research advisor, and Mr. Gates, Director of the City-County Council on Aging, to discuss the feasibility of using such a measurement. Adequate revisions were made according to their suggestions. for State Survey's On Aging and Marilyn Langford, (1962).

The health conditions listed in question \#67 represent the most prevalent health conditions as found in a study of OAA recipients published by the Department of Health, Education and Welfare. This information can be found in the publication, Old Age Assistance Recipients in 1965: Health Conditions and Health Services.

The U. S. House Ways and Means Committee report on the "Family Assistance Act of 1970 " supplied us with the poverty line for 1969 which was used as our lowest income category in question \#72. The occupational categories in question \#74 were based on the Occupational Outlook Handbook, compiled by the U. S. Department of Labor, Bureau of Labor Statistics. 


\section{PRETESTS AND PRECAUTIONS}

Pretests were given to six elderly male and female respondents, all of whom were comparable to the people in our sample. Those people were 62 and older, their sole income was Social Security and/or Old Age Assistance benefits, and they lived alone in very inexpensive housing.

The first four pretests were examined for content validity by comparing a respondent's answers on all questions measuring a particular variable. It was found that the scores for all questions measuring a particular variable were similar within each interview conducted. As a result, we assumed the content consistency of our measurement to be satisfactory.

The fifth pretest was examined for reliability by giving the same test to the same person on two separate occasions, three weeks apart. ${ }^{3}$ The following table shows the result of this test:

TAB LE I

RELIABILITY TEST RESULTS

\begin{tabular}{lccc}
\hline & $\begin{array}{c}\text { Independence } \\
\text { Score }\end{array}$ & $\begin{array}{c}\text { Loneliness } \\
\text { Score }\end{array}$ & $\begin{array}{c}\text { Willingness to } \\
\text { Roommate Score }\end{array}$ \\
\hline lst Test & 52 & 31 & 31 \\
2nd Test & 51 & 27 & 29 \\
Difference & 1 & 4 & 2 \\
\hline
\end{tabular}

${ }^{3}$ We planned to conduct reliability tests on both pretest 5 and 6 but the 6 th respondent was not available for retest due to illness. 
The scores of all the sociological variables remained the same. There was a slight change in the scores, but all differences were minimal. ${ }^{4}$ As a result, the measurement was judged to be reliable.

During the four month interviewing period, the two student researchers met regularly to discuss the questionnaire and any judgments they had made in classifying answers to be certain that individual differences of interviewers would be reduced.

\section{SCORING TECHNIQUE}

When constructing our questionnaire, we chose to use fixed response questions which were easily scored. It was necessary to establish scoring categories based on an ordinal scale. Many questions were constructed similar to the Iikert-type scale in which subjects were asked to respond in degrees of agreement or disagreement. In most cases, questions were constructed so that three choices were possible--each representing a different level of the variable in question.

Answers were tabulated as " $A$ ", " $B$ " and " $C$ " in such cases.

4 The greatest difference occurred in the measurement of loneliness where the respondents score was four points lower the second time the test was given. The interviewer believes this score might have been affected by the following factors: (1) the interviewer was a familiar person, no longer a stranger; (2) the respondent had just returned from spending one week babysitting; (3) the subject had just received an invitation to dinner three days hence. 
Various demographic variables consisted of more or less than three categories. Only health (questions 64-67); Social activity (75-77); length of time separated (63); living alone (71); and living in Portland (70) were coded on three level scale similar to the psychological variables. The other sociological variables were tabulated only as simple demographic data without any value judgments being made. After tabulating the data (A, B, C-style) on a simple answer sheet, the answers were transposed from letters to numbers (i.e. 1 , $2,3)$ according to the value of the answer. For example in question \#13, an "A" would be transposed to a " 3 " which would mean it represented a high degree of independence. Since there was no constant number value for each letter (for example " $A$ " did not equal "3" in all questions) a legend or score sheet was constructed. In all but the simple demographic data, "l" represents a low level of the variable, "2" a neutral or middle degree and " 3 " a high degree.

Table II represents the questions related to each psychological variable and the possible range of scores.

After preliminary assessment it was determined that several questions were not meaningful measurements of the variable they were constructed to measure. Questions number 23,24 , and $25^{5}$ were originally included as measurements of independence. In our second

${ }^{5}$ These three questions deal with whether or not a person chose to retire. 
analysis we decided these questions were not a measure of independence, but rather demographic indicators. For the purposes of data analysis, the scoring categories of some questions were also refined. A copy of these revisions can be found in the appendix.

TABLE II

RANGE OF SCORES

\begin{tabular}{lcc}
\hline VARIAB IE & QUESTIONS & RANGE OF SCORES \\
\hline Independence & $1-22,26$ & $23-69$ \\
Loneliness & $27-44$ & $18-54$ \\
$\begin{array}{l}\text { Willingness to } \\
\text { Roommate }\end{array}$ & $45-59$ & $15-45$ \\
\hline
\end{tabular}

\section{RESEARCH DESIGN}

This study was constructed in order to answer four principal questions:

1. What are the characteristics of the sample? This includes descriptive-demographic data and frequency of scores distribution.

2. What a re the relationships of loneliness and independence to willingness to roommate, and of loneliness to independence?

3. What are the correlations between all of the demographic and psychological variables?

4. Based on these correlations, what are the common characteristics of those who are willing to roommate? 
In order to answer these questions, we devised a research design in which three basic models were used. The first analyzes the existence of a correlation between each of the independent variables and the dependent variable (i.e. willingness to roommate). This is illustrated in Table III.

The second model used was that of a partial correlation in order to find the relationship of loneliness and independence to willingness to roommate, controlling the influence of all the other variables. This is shown in Table IV and Table V.

Simple intercorrelations of all variable combinations were also made. This model is shown in Table VI. 
TAB LE III

\section{RESEARCH MODEI SIMPIE CORREIATIONS}

Psychological
Variables

Demographic Variables

\begin{tabular}{|l|}
\hline $\begin{array}{l}\text { Independence } \\
\text { Loneliness }\end{array}$ \\
\hline Marital Status History \\
Age \\
Separation Time \\
Health \\
Religion \\
Length of Time Living Alone \\
Portland Residence \\
Education \\
Income \\
Occupation \\
Degree of Activity \\
\hline
\end{tabular}

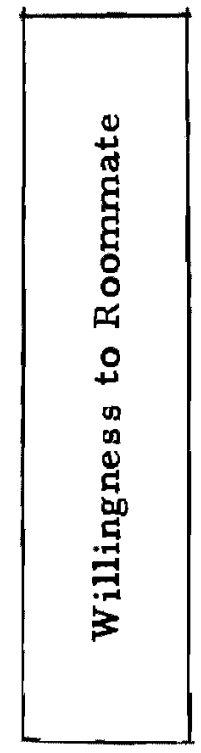

TAB IE IV

RESEARCH MODEI

PARTIAL CORRELATION: INDEPENDENCE AND

WIILINGNESS TO ROOMMATE

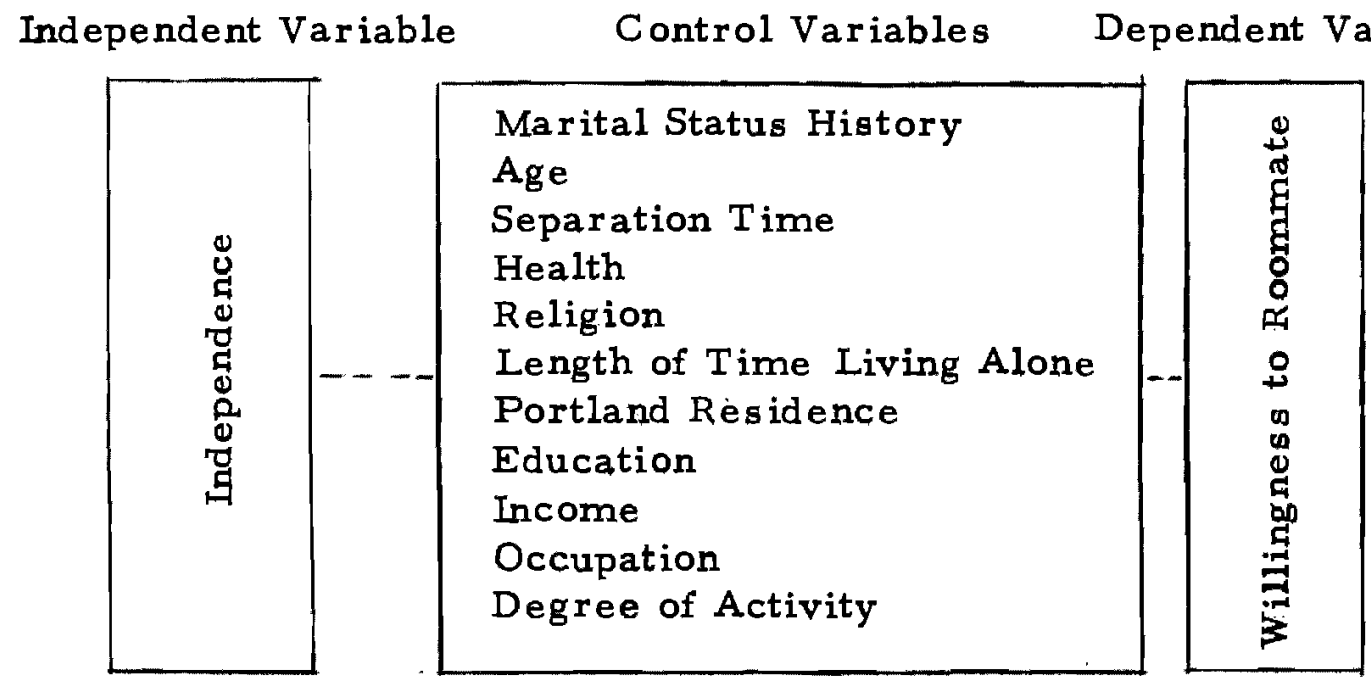


TAB LE V

RESEARCH MODEI

PARTIAL CORREIATION: LONELINESS AND

WIL LINGNESS TO ROOMMATE

Independent Variable

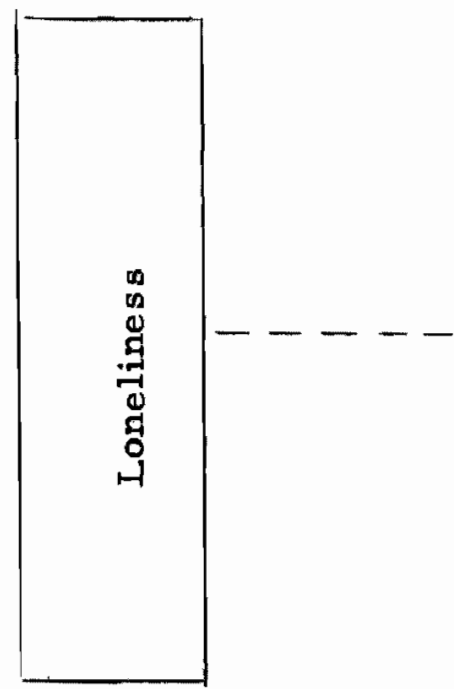

Control Variables Dependent Variable

Marital Status History

Age

Separation Time

Health

Religion

Length of Tirne

Living Alone

Portland Residence

Education

Income

Occupation

Degree of Activity

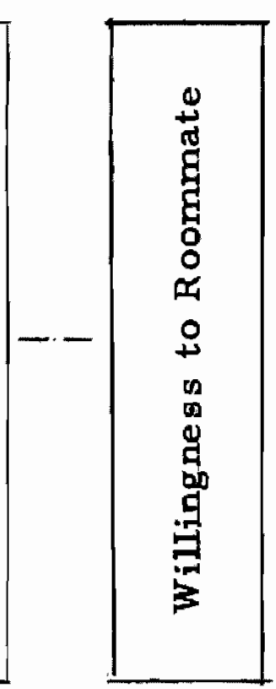


TABLE VI

RESEARCH MODEI

SIMPLE INTERCORREIATIONS MA TRIX

\begin{tabular}{|c|c|c|c|c|c|c|c|c|c|c|c|c|c|c|}
\hline & Lonel. & $\begin{array}{l}\text { Will- } \\
\text { ing- } \\
\text { ness }\end{array}$ & Sex & Age & $\begin{array}{l}\text { Mari- } \\
\text { tal } \\
\text { St. }\end{array}$ & $\begin{array}{l}\text { Sep. } \\
\text { Time }\end{array}$ & $\begin{array}{l}\text { Hea- } \\
\text { lth }\end{array}$ & Rel. & $\begin{array}{l}\text { Part. } \\
\text { Res. }\end{array}$ & $\begin{array}{l}\text { Time } \\
\text { Alone }\end{array}$ & $\begin{array}{l}\text { In- } \\
\text { come }\end{array}$ & Educ. & Occup. & $\begin{array}{l}\text { Act- } \\
\text { ivity }\end{array}$ \\
\hline Loneliness & & $W \times I$ & SxL & AxL & MSxL & STXL & HxI & $\mathbf{R x L}$ & PRxI & TAXLL & INxI & ExL & OxL & $A C x L$ \\
\hline Willingness & & & SxW & AxW & MSxW & STXW & $\mathrm{HxW}$ & $\mathbf{R x W}$ & PRxW & TAxW & INXW & ExW & OxW & $A C x W$ \\
\hline Sex & & & & $A \times S$ & MSxS & STxS & $\mathrm{HxS}$ & $\mathbf{R x S}$ & PRxS & TAxS & INxS & ExS & OxS & $\mathrm{ACxS}$ \\
\hline Marital Status & & & & & & STXMS & HoxMS & RxMS & PRxMS & TAxMS & IN $x M S$ & ExMS & OxMS & ACxMS \\
\hline Sep. Time & & & & & & & $\mathrm{HxST}$ & RxST & PRXST & TAxST & INxST & ExST & OxST & ACXST \\
\hline Health & & & & & & & & $\mathbf{R x H}$ & PRxH & TAxH & INxH & ExH & OxH & $A C x H$ \\
\hline Religion & & & & & & & & & PRxR & TAxR & INxR & ExR & OxR & $A C x R$ \\
\hline Portland Res. & & & & & & & & & & TAxPR & INbxPR & ExPR & OxPR & $A C x P R$ \\
\hline Time Alone & & & & & & & & & & & INxTA & ExTA & OxTA & ACXTA \\
\hline Income & & & & & & & & & & & & ExI & OxI & AcxI \\
\hline Education & & & & & & & & & & & & & OxE & $A C x E$ \\
\hline
\end{tabular}


CHAPTER III

\section{COLLECTION AND ANALYSIS OF DATA}

\section{COLLECTION OF DATA}

Specific preliminaries to the actual collection of data included the sending of 220 letters of introduction to the people in the population. A second, reminder letter, was sent to the 180 who had not replied within a two month period. Both letters are included in the appendix. A total of 99 people answered the letters; 64 accepting the request, 35 explaining why they we re unable to participate in the research study. Reasons which non=participants mentioned included health, inappropriate age, new residence and fear of being evicted.

About four months (August-December, 1970) was spent interviewing the elderly people in the sample. Both student researchers conducted the interviews, each student interviewing 25 to 30 people. Interviews were conducted in the homes of the respondents and at their convenience. All questions were asked uniformly. Explanations of questions were provided as needed until the interviewers felt assured that they were understood by the respondent and that they understood the meaning of the response.. Each respondent was allowed time to elaborate on each question, although this was somewhat limited by the 
time available. The average interview lasted 45 minutes, while interview length ranged from 30 minutes to three hours. Interviewer-bias was apparent in the time factor. The male student's average interview lasted 30 minutes while the average length of time for the female student's interview was one hour and ten minutes. Although constant communication was maintained to minimize interviewer bias, some individual differences cannot be discounted.

After each interview, the purpose of the research was explained to the respondent, reassuring him if necessary and attempting to help him feel free to discuss the variables of interest in a casual manner. It was observed that because they were relaxed at this time, the elderly people were able to be more open about their personal philosophy, opinions, and desires. Due to the size of the sample, the interviewers were able to spend more time with each respondent and thereby receive more in-depth information and a better overall understanding of the individual in relation to the study.

Generally, the interviewers received a warm reception accompanied by a cup of coffee. Many people in the sample apparently enjoyed having a visitor and talked a great deal. The interviewers were also aware of a prevailing fear factor. Some expressed fear that the interviewers were from the Housing Authority and would evict them or raise their rent. Two women were too fearful to allow the interviewer into their apartments. Another woman allowed the interview to take 
place, calling the school immediately afterwards requesting reassurance that she would not be evicted. This fear factor must be kept in mind as the results of this study are read.

\section{SAMPLE DESCRIPTION}

Of the 56 respondents in the sample, seven were men and 49 were women. Only nine respondents were under 69 years including all of the male respondents; 26 respondents were between $70-79$ years old, and 21 of the people interviewed were 80 years and older.

Four respondents had never been married including two men, Forty-five respondents were widowed, five were separated from their spouse, and two were divorced. The length of time a respondent had been separated from his spouse by death, separation, or divorce varied greatly: five respondents had been separated one to five years, six had been separated six to ten years, and forty-two had been separated for over ten years.

The length of time the respondents had lived alone varied from five living alone less than three years, ten living alone three to six years, to forty-one living alone more than six years. Fifty-one persons had lived in Portland more than six years; three have lived in Portland from three to six years and only two had resided in Portland less than three years.

Table VII gives the health characteristics of the sample according 
to the number of respondents in four categories: visits per year to the doctor, pills taken per day, time in the bospital, and the number of conditions or diseases.

TAB LE VII

NUMBER OF RESPONDENTS ACCORDING

TO EACH HEALTH CATEGORY

\begin{tabular}{l|l||l|l||l|l||l|l}
\hline $\begin{array}{l}\text { No. of Doctor } \\
\text { Visits Per Year }\end{array}$ & N & $\begin{array}{l}\text { Pills } \\
\text { Per Day }\end{array}$ & N & $\begin{array}{l}\text { Time In } \\
\text { Hospital }\end{array}$ & N & $\begin{array}{l}\text { No. of Conditioms } \\
\text { or Diseases }\end{array}$ & N \\
\hline 3 or less & 23 & 1 or less & 27 & No Time & 20 & None & 13 \\
4 to 7 & 15 & 2 to 5 & 23 & 1 to 5 wks & 24 & 1 Condition & 20 \\
8 or more & 18 & 6 or more & 6 & 6 whs or more & 12 & 2 or more & 23 \\
\hline
\end{tabular}

Most of the respondents were white, poor and members of a Christian faith. Table VIII gives the number of respondents in each category.

TABLE VIII

NUMBER OF RESPONDENTS ACCORDING TO INCOME, RACE, AND RELIGION

\begin{tabular}{lccccccc}
\hline Variable & $\begin{array}{c}\$ 1,900 \text { or } \\
\text { less }\end{array}$ & $\begin{array}{c}\text { Above } \\
\$ 1,900\end{array}$ & White & Black & Christian & Other \\
\hline Number & 44 & 12 & 55 & 1 & 55 & 6 \\
\hline
\end{tabular}


Thirty-five of the respondents had some education beyond the eighth grade; seventeen persons had an eighth grade education or less, and fifteen were educated beyond high school. One respondent was a man with a Ph. D. in education. The occupational breakdown and number of respondents for each occupational category is shown in Table IX. About $68 \%$ of the total sample comprised the clerical and sales, skilled and unskilled categories.

TAB LE IX

NUMBER OF RESPONDENTS IN EACH OCCUPATIONA L CATEGORY

\begin{tabular}{ccccc}
\hline Professional & Business & Clerical \& Sales & Skilled & Unskilled \\
\hline 10 & 8 & 17 & 14 & 7 \\
\hline
\end{tabular}

The retirement age was varied for this sample. Twenty-six people retired when they were 64 or younger, seventeen retired between 65-69 years old, and five retired at 70 years or older. Eight persons never retired because they never worked, were housewives, or were still working part-time. Table $X$ gives the number of respondents choosing or being forced to retire and the reasons for retirement. 
TABLE $X$

NUMBER OF RESPONDENTS RETIRED AND

REASONS FOR RETIRING

\begin{tabular}{|c|c|c|c|}
\hline \multicolumn{2}{|c|}{ Voluntary Retirement } & \multicolumn{2}{|c|}{ Forced Retirement } \\
\hline Number & Reason & Number & Reason \\
\hline 11 & Other Interests & 22 & $\begin{array}{l}\text { No longer able to } \\
\text { work }\end{array}$ \\
\hline \multirow[t]{2}{*}{9} & Health Reasons & 4 & Company Policy \\
\hline & & 2 & Other Reasons \\
\hline
\end{tabular}

III. CORRELATIONS BETWEEN EACH OF THE INDEPENDENT VARIABLES AND WILLINGNESS TO ROOMMATE

Table XI gives the information found by putting the coded data through an IBM 1130 computer.

Negative means appear in Table XI for the variables sex and marital status. Sex was scored with a 1 representing male and a -1 representing female. The negative mean shows more females than males in the sample. Marital status was scored with a 1 representing those who were never married and a -1 representing those who were once married. The negative mean shows most respondents were once married. The variable income was scored as an average of grouped data to obtain the mean. 
TAB LE XI

MEANS, STANDARD DEVIATIONS, AND CORRELATION COEF FICIENTS OF VARIAB LES CORRELATED

WITH WILIINGNESS

\begin{tabular}{lrcc}
\hline \multicolumn{1}{c}{ Variable } & Mean & $\begin{array}{c}\text { Standard } \\
\text { Deviation }\end{array}$ & $\begin{array}{c}\text { Correlation } \\
\text { Coefficient }\end{array}$ \\
\hline Willingness to Roommate & 24.86 & 5.37 & \\
Independence & 56.12 & 5.11 & .27 \\
Loneliness & 26.23 & 4.45 & -.17 \\
Sex & -0.75 & .66 & -.11 \\
Age & 2.21 & .71 & .07 \\
Marital Status & -0.85 & .51 & -.23 \\
Separation Time & 3.21 & 1.99 & -.26 \\
Health & 8.41 & 2.05 & .09 \\
Religion & .79 & .62 & .10 \\
Portland Residence & 2.85 & .44 & -.11 \\
Time Alone & 2.64 & .64 & -.18 \\
Income & 1.33 & 1.11 & -.01 \\
Education & 1.93 & .75 & -.02 \\
Occupation & 3.00 & 1.28 & .00 \\
Number of Activities & 47.75 & 18.85 & .04 \\
& & & \\
\hline
\end{tabular}

The psychological variables, independence and loneliness, were correlated with willingness to roommate using the Personian $r$. These correlations are found in Table XI. There is a relatively small positive correlation between willingness to roommate and independence, $r=.27$. Although this correlation is small, there is a slight indication that the higher a respondent's independence score, the more likely he is to be willing to roommate. Although there is a relatively low negative correlation, $r=\ldots 17$, between loneliness and willingness, there is a slight indication that the higher a respondent's loneliness score, the 
less likely he is to be willing to roommate.

The twelve demographic variables were correlated with willingness and these correlations are in Table XI. The correlation between sex and willingness is negative and the degree of correlation is so small that it can be concluded that sex makes little difference in the study of a respondent's willingness to roommate, $r=-.11$. Since there were only seven men in the sample, very little correlation was expected. The correlation between age and willingness is so small, $r=.07$, it is not meaningful. Age means very little in explaining a person's willingness to roommate in this study. Marital status and willingness have a relatively low negative correlation, $r=-.23$. This means that if a respondent has never been married, he is less likely to want another elderly person as a roommate. Those who were once married are more likely to want a roommate. Since such a small correlation exists between health and willingness, $r=.09$, health in this study makes little difference in a respondent's willingness to roommate.

The relationship between religion and willingness is a relatively low positive correlation, $r=.10$. This is such a small correlation that it does not really provide any meaningful information. Length of residence in Portland is correlated with willingness in a relatively low negative correlation, $r=-.11$. This means that the longer a respondent has lived in Portland, the less likely he is to want a roommate. The 
correlation between time alone and willingness is a relatively low negative correlation, $r=-.18$, meaning that the longer a respondent has. lived alone the less likely he is to want an elderly roommate. The conclusion that the variables income, education, and activities have little influence on a respondent's willingness to roommate is based on the very small correlation coefficients between these variables and willingness to roommate.

TAB LE XII

MULTIPLE CORRELATIONS OF LONE LINESS, INDEPENDENCE, AND DEMOGRAPHIC VARIABLES TO WILIINGNESS

TO ROOMMATE

\begin{tabular}{lccc}
\hline \multicolumn{1}{c}{ Variable } & $\begin{array}{c}\text { Multiple } \\
\text { Correlation }\end{array}$ & $\mathrm{R}^{2}$ & $\%$ \\
\hline Willingness with all variables & .46 & .21 & 21 \\
Independence excluded & .34 & .12 & 12 \\
Loneliness excluded & .45 & .20 & 20 \\
Demographic excluded & .31 & .10 & 10 \\
\hline
\end{tabular}

From Table XII, it can be seen that if independence is excluded and all other variables are correlated with willingness, the multiple correlation is reduced by $.12(.46-.34=.12)$. If loneliness is excluded, the multiple correlation is reduced by $.01(.46-.45=.01)$. It seems again that loneliness had very little influence on a respondent's willingness to roommate. Independence has the greatest 
influence on a person's willingness to roommate in this study.

From Table XII when all fourteen variables are correlated with

willingness, the influence of all variables accounts for only $21 \%$ of a respondent's willingness to roommate. This means that $79 \%$ of the influence on a respondent's willingness to roommate is explained by variables unknown and unaccounted for in this research. This will be covered in more detail in Chapter IV.

If independence is excluded from the correlation with willingness, $12 \%$ of the influence is explained by loneliness and the demographic variables. In other words, independence explains nine percent correlation of all variables to willingness $(21 \%-12 \%=9 \%)$. If loneliness is excluded, there is a one percent difference from when all variables are correlated together $(21 \%-20 \%=1 \%)$. Therefore, loneliness explains only one percent of the influence of all variables on willingness. If the demographic variables are excluded from the correlation, there is an $11 \%$ difference $(21 \%-10 \%=11 \%)$ from when all variables were correlated. This means that the twelve demographic variables account for $11 \%$ of the correlation of all variables to willingness.

In interpreting these percentages, it can be said that in this study the variable independence influences a respondent's willingness more than any other single variable. Loneliness influences a respondent's willingness less than any other single variable. The demographic variables acting together can explain $11 \%$ of the variation in a 
respondent's willingness to roommate. Other variables seem to influence an elderly person's willingness to roommate. These will have to be found in further research.

TABIE XIII

MEANS, STANDARD DEVIATIONS, AND POSSIBLE RANGES OF INDEPENDENCE, LONELINESS, AND WILLINGNESS

\begin{tabular}{lccc}
\hline \multicolumn{1}{c}{ Variable } & $\bar{X}$ & S. D. & Possible Range \\
\hline Independence & 56.12 & 5.11 & $23-69$ \\
Loneliness & 26.23 & 4.45 & $18-54$ \\
Willingness & 24.88 & 5.37 & $15-45$ \\
\hline
\end{tabular}

Table XIII contains information to explain where most of the sample scored according to the possible degrees of independence, loneliness and willingness. The independence $\bar{X}=56.12$ and the possible range is 23-69. Two standard deviations from the mean tells us the $95 \%$ of the sample scored between 46-66. This indicates that most of the sample have a high independence score. The loneliness mean is 26.23 and the possible score range is 18-54. Two standard deviations from the mean reveal that $95 \%$ of the sample scored between 17-35. This indicates that most of the sample have a low loneliness score. The $\bar{X}$ for willingness is 24.88 , with a possible range of 15-45. Two standard deviations from the mean show that $95 \%$ of the sample scored between 14-36. This indicates that most of the sample have a low 
willingness to roommate score.

IV. SIMPLE GORRELATIONS

TABIE XIV

MEANINGFUL CORRELATIONS OF VARIABIES

\begin{tabular}{|c|c|c|c|c|c|c|c|c|c|c|c|c|c|}
\hline & 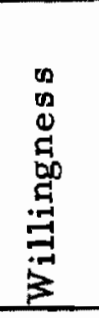 & $\begin{array}{l}x \\
\vdots \\
\\
\end{array}$ & $\begin{array}{l}0 \\
0 \\
4\end{array}$ & 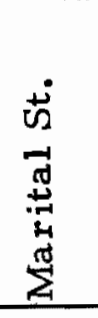 & $\begin{array}{c}\stackrel{g}{E} \\
\dot{H} \\
\dot{0} \\
\dot{D} \\
\dot{0}\end{array}$ & 吾 & 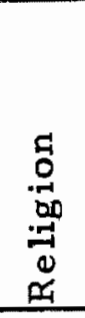 & 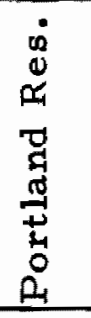 & 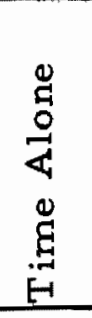 & 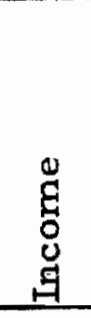 & 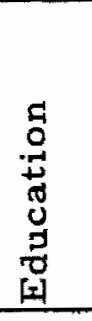 & 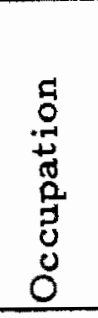 & 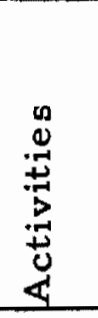 \\
\hline Independence & .27 & & .25 & & & .23 & & $=21$ & & & & & \\
\hline Loneliness & & .31 & & .33 & .31 & & & & & & .25 & $=27$ & .24 \\
\hline Willing ness & & & & -23 & .26 & & & & & & & & \\
\hline Sex & & & & .31 & .31 & & .21 & & & .32 & & & \\
\hline Marital Status & & & & & .95 & & & & & & & & $: 21$ \\
\hline Sep. Time & & & & & & & & & .34 & & & & .31 \\
\hline Time Alone & & & & & & & & & & & & & .25 \\
\hline Income & & & & & & & & & & & .22 & & \\
\hline Education & & & & & & & & & & & & .58 & \\
\hline
\end{tabular}

In Table XIV, the correlations that are meaningful for all variables are listed. A table of all possible simple correlations appears in the appendix.

The correlation coefficient (Personian $r$ ) of independence and age is -.25 , meaning that the younger a respondent is, the more likely he is to be able to do things unaided. Independence has a small 
positive correlation to health. This means that the healthier a respondent is, the more likely he is to be able to do things unaided. Those individuals living in Portland the longest are less likely to be able to do things unaided. Those respondents living in Portland the shortest time are more likely to be more independent.

Loneliness and sex have a small positive correlation, $r=.31$. This indicates that a male respondent is more likely to be lonely than a female respondent. It is interesting to note that a similar correlation exists between loneliness and marital status; if a respondent has never been married, he is more likely to be lonely. Loneliness and separation time have a small positive correlation, meaning that the longer a respondent has been separated from his spouse, the more likely he is to be lonely. Loneliness is negatively correlated with education, occupation and number of activities. The more education a person has, the less likely he is to be lonely; the professional and business people are less likely to be lonely than the skilled and unskilled people in our sample. The more activities a respondent participates in, the less likely he is to be lonely.

Willingness to roommate is negatively correlated with marital status and separation time. Those respondent's who have never been married are less likely to be willing to roommate than those who were once married. Those respondents who have been separated the longest are less likely to be willing to roommate than those who have been 
separated a shorter period of time.

Sex is correlated positively with marital status and length of separation. This means that the men in the sample are more likely to have never been married. Those men that were once married are more likely to be separated longer than a female respondent. Religion and sex have a low negative correlation. This could mean that the men in the sample are less likely to be members of a Christian religion than the women; however, since there are so few men in the sample, there is not enough information to explain this relationship. Sex is positively correlated with income which means that the male respondents are more likely to have a higher income than the female respondents.

Marital status has a high positive correlation with separation time, but is negatively correlated with number of activities. Thus respondents who have never been married are more likely to have fewe $r$ activities. Length of separation has a relatively low positive correlation with time alone; those being separated the longest are more likely to have lived alone the longest. Those who have been separated from their spouse the longest are less likely to be involved in many activities.

Time alone and number of activities are positively correlated explaining that the longer a respondent has lived alone, the less likely he is to participate in many activities. Income and education are 
positively correlated; therefore, the higher a respondent's education, the more likely he is to have a higher income. Occupation and education are positively correlated, explaining that the more education a respondent has had, the more likely he is to have had a better job.

\section{ANALYSIS OF WILIINGNESS TO ROOMMATE QUESTIONS}

The willingness to roommate questions are questions 45-59. Table XV contains the number of people answering each response for these questions.

TAB LE XV

RESPONDENT'S ANSWERS TO WILIINGNESS TO ROOMMATE QUESTIONS

\begin{tabular}{|c|c|c|c|c|c|c|c|c|c|c|c|c|c|c|c|c|}
\hline Question & & 45 & 46 & 47 & 48 & 49 & 50 & 51 & 52 & 53 & 54 & 55 & 56 & 57 & 58 & 59 \\
\hline & 1 & 47 & 25 & 35 & 34 & 34 & 46 & 28 & 18 & 49 & 20 & 40 & 32 & 38 & 30 & 26 \\
\hline \multirow[t]{2}{*}{ Response } & 2 & 3 & 7 & 13 & 11 & 10 & 8 & 22 & 22 & 4 & 15 & 5 & 22 & 14 & 12 & 6 \\
\hline & 3 & 6 & 24 & 8 & 10 & 12 & 2 & 6 & 16 & 3 & 21 & 11 & 2 & 4 & 14 & 21 \\
\hline
\end{tabular}

The questionnaire which appears in the appendix should be used as a guide for the following discussion.

The respondents' answers to question 45 ("Do you prefer to live alone?") indicates that $84 \%$ prefer to live alone and $10 \%$ would rather live with others. For question 46 ("Would you mind sharing your bathroom with another elderly person?"), the respondents gave answers 
which indicate that $50 \%$ are willing to share and $50 \%$ are not willing to share their bathroom. The answers given for question 47 ("Would you be willing to share expenses for rent for an apartment with another elderly pers on of the same sex?") imply that $63 \%$ of the sample are not willing to share expenses for rent.

Questions 48 through 50 are combined into one question, "Would you be willing to live with the following persons?" Question 48 concerns living with relatives, and $62 \%$ of the sample answered that they would not be willing to live with relatives. Question 49 concerns living with friends, and $62 \%$ of the sample felt that they would not be willing to live with friends. Question 50 concerns living with someone an elderly person does not know; $82 \%$ would not be willing to live with someone they did not know. It is interesting to notice that the number of respondents answering each category for questions 48 and 49 a re quite close. This might indicate that for elderly people in the sample, there is little difference between their willingness to live with relatives and their willingness to live with friends. Further research should be attempted to investigate what relationship exists here. The majority of respondents answered question 51 ("Suppose you had to share your furniture with another elderly person what would be your reaction to this ?"), indicating they were indifferent or would dislike sharing their furniture. Question 52 poses a problem. "Suppose you have to move out of your present living arrangement because of an 
eviction notice. Would you be willing to move in with another elderly person of the same sex who was someone you knew and someone you would feel compatible with?" A close percentage of respondents answered this question in all three categories; however, the highest number would be willing to move in with another elderly person only if it were a temporary arrangement.

The responses to question 53 ("Suppose you lived alone in an apartment would you appreciate the opportunity of being able to be by yourself?") indicate that $88 \%$ appreciate the opportunity to be alone. To question 54 ("Suppose someone from a social service agency came to you and stated he knew some elderly people that needed a place to live. Would you be willing to have one of these elderly people move in with you?"), almost an equal number answered that they would be willing or they would not consider it. Twenty-six percent would have to think about it. This indicates that some of the people interviewed would help another elderly person if necessary.

The answers to question 55 ("If you could have either privacy or companionship in your living ar rangement which would you prefer?") indicated that $71 \%$ prefer privacy over companionship in their living arrangement. When some of the respondents were asked this question they stated a preference for the companionship they enjoyed when their deceased spouse was living.

To question 56 ("Suppose a nother elderly pers on you knew invited 
you to move in with him. What would be your reaction to the idea of living with this person?"), a majority of respondents answered that they would not be excited about such an offer. Thirty-nine percent stated they would have to think about it. To question 57 ("Would you consider moving if the Housing Authority let you live with another elderly person without increasing your rent? The two of you together would pay as much as you are now paying alone.") $68 \%$ answered "no" to this question.

Fifty-three percent of the respondents to question 58 ('Suppose you have a friend come to stay with you from out of town who is rather sloppy, i.e. does not hang up his clothes, does not rinse out the bathtub, or leaves his dirty dishes without washing them. How would you feel about inviting your friend to come and stay again?") answered that they would never invite their friend back again. The answers to question 59 ("Would you find it difficult to plan your meals with another person?") indicate that a high number of respondents $(46 \%)$ would find it difficult and a smaller number $(37 \%)$ would not find it difficult to plan their meals with another person.

The next chapter will set forth the conclusions these researchers have drawn from analysis of the findings described in this chapter. Recommendations will also be made for future research to begin where this project ended. 


\section{CHAPTER IV}

\section{DISCUSSION, CONCLUSIONS, LIMITATIONS}

AND RECOMMENDATIONS

In this chapter data will be interpreted and the results of the research will be explained in meaningful terms.

\section{DISCUSSION}

The variable of independence has a higher correlation with willingness to roommate than any of the other variables. In other words, independence influences a person's willingness more than any other single variable in the study. This was discussed in Chapter III where it was mentioned that independence accounted for nine percent of a person's willingness.

Although the correlation between willingness and independence was not large, the direction was very significant. The researchers expected to find independence negatively correlated with willingness, but it was not. Apparently, the more able one is to do things unaided, the more likely he is to be willing to roommate. We can only speculate about the possible meaning of such a correlation. Perhaps the more one is able to do things unaided, the better his self concept. Perhaps one must see himself as strong and able in order to accept 
the stress and challenge of the intimate interaction of living with a roommate.

It can also be speculated that the person who feels he can do things unaided has retained the psychological strength to continue enjoying social encounters. For example, one woman said she enjoys her "independence very much" and that she felt too restricted "once when she lived with a family while convalescing." This woman scored much below average on the test of independence. Perhaps she felt restricted because she did not have the ability to handle the intimate encounter of living with another person. There were many other respondents who expressed the feeling that as they get older and sees themselves as less able to do things unaided, they find it more difficult to share in the day to day give and take of living with another person.

Two women were quite similar in their above average independence scores and their feelings about roommates. Both of these women said they would like a roommate "if she was congenial and would help with the work and share expenses." Both also felt that apartment life was excellent for the old because "old people who live alone in a house need someone else." These two women did not know each other, nor did they live in the same housing complex, yet their feelings about living with a nother were quite similar. There were a few other people who expressed similar feelings.

Returning to the discussion of possible explanations for the 
direction of the correlation between independence and willingness to roommate, it is possible that a person who feels he can do things unaided may find it easier to rationalize that he is roommating for the sake of the other since he is really able to care for himself. In this way, he will not have to admit needing or benefiting from the social contact and personal assistance which he would derive from a roommate. Some of the people interviewed had done volunteer work. Many of these people seemed to equate living with a roommate with doing volunteer work for a more dependent person.

For example, in question 54 people were asked if they would be willing to take in another elderly person who was homeless. Twentyone people said they would be willing to try it and another fifteen said they would think about it. Comments to this question included "I would be willing to help someone," and "If someone really needed a home, $I^{\prime} d$ take him in temporarily."

Generally, the people in the sample are able to do most things mentioned ir the measurement without the assistance of others. Therefore, by our standards, they are independent.

Some of the comments the respondents made regarding their independence further support the data in this area. Such comments include, "I would rather do things for myself as long as I am able to" and "I don't want to be a burden on anyone."

Many people found some of the independence questions amusing 
because they said they had no difficulties in these areas. They seemed very proud of this. One woman took great pride in living alone and in her ability to care for herself. Another woman who wore a brace on her leg explained in great detail how she walks several miles a day and is able to care for herself.

Independence has a high enough correlation with age, health and Portland residence to give some interesting findings. Since age is negatively correlated with independence, it can be concluded that the younger respondents in the sample are likely to be more independent than the older respondents.

The independence of the younger respondents is not related to their health since the younger members of the sample are not necessarily healthier than the older members. The positive correlation between independence and health indicates that those respondents who are healthier are more likely to be the most independent people in our sample. The negative correlation between independence and Portland residence indicates that those individuals living in Portland the longest are likely to be less independent than those individuals living in Portland only a short time. The findings indicate that those respondents who are the most independent are more likely to be younger, healthier, and have lived in Portland less time than those respondents who are more dependent.

The correlation between independence and loneliness is 
extremely low, showing no meaningful relationship. The correlation between loneliness and willingness is also low. Surprisingly, the direction of this relationship is negative, indicating that the lonelier a respondent is, the less willing he is to roommate. Since loneliness is the smallest single variable influencing a person's willingness to roommate, it can be concluded that its influence is minimal as defined for this study. This might be explained by the low loneliness scores of the people in the sample. Since these people are not very lonely, the influence of loneliness on willingness is negligible.

We might also speculate that the low degree of feeling of being alone is due to the high degree of participation in activities since the correlation between loneliness and activities is negative, indicating that the more active a person is, the less lonely he will be.

Another possible explanation for so many people in our sample not feeling lonely is that they live in apartments or housing complexes where there were many other people with similar backgrounds, of the same economic status, and of similar age. These people were all further united by belonging to the Housing Authority and, in some cases, by participating in many of the same social activities. Posr. sibly due to the close proximity and commonalities of neighbors, loneliness was not such a grave problem.

The comments of many of the respondents support this hypothesis: "Public housing is great. . have people a round enough and 
plenty to do yet I can get away to be by myself when I want to." Another woman who lived in a court, said she enjoyed this very much because she can "visit with friends and neighbors as often as I like" and still "read all night if I want to."

It is apparent to these researchers that there is a stigma attached to loneliness. Possibly, many people are too proud to admit to being lonely or feeling alone. Others see loneliness as a personal failure. One woman stated that she cannot understand how people can feel lonely. She believes they "just sit around all day feeling sorry for themselves." Her reaction to loneliness is "to get out of the house and do something." Another woman also said she finds "it difficult to understand people who complain about being lonely" since she feels a person can keep himself happy and must count his blessings.

Those who were never married were lonelier than those people who had been married, yet the significance of this statement is minimal since only four people in the sample had never been married.

The data also indicated that the longer someone was separated from his spouse, the more likely he was to be lonely. Men tended to be lonelier than woman. Again, this data is not heavily supported since there were only seven men in the sample.

The correlation between loneliness and education and occupation was negative, indicating that the better educated pers on and the person who held a higher status job were less lonely than the others. 
The correlations between loneliness and age, health, religion, Portland residence, time alone, and income are not large enough to be meaningful.

Analysis of the demographic variables showed that they accounted for $11 \%$ of the influence on an elderly person's willingness to roommate, a high enough percentage to supply important information. Marital status is negatively correlated with willingness; indicating that those respondents who were once married are more likely to be willing to roommate. The relationship between marital status and willingness could indicate that once a person has experienced the companionship in marriage, he is more responsive to the idea of roommating. Possibly, someone who has lived alone for the majority of his life has become so adjusted to life alone that he does not find the idea of a roommate at all appealing. This explanation is only speculation on our part.

Data from the study also indicates that those people who have been separated from their spouse the longest are least likely to want an elderly roommate. Also, the data indicates that those elderly people who have lived alone for a long time probably do not want a roommate.

According to the findings, the demographic variables sex, age, health, religion, income, education, occupation and activities do not significantly influence an elderly person's willingness to roommate. 
Because the sample was so similar in these areas, the lack of variation discounted any meaningful comparison.

The people in the sample scored low on willingness to roommate. With a possible range of scores from $15-45,95 \%$ of the scores were between 14 and 36. Comments made by the respondents further illustrate this negative attitude towards living with someone.

One woman went into a lengthy discussion of all the disadvantages of having a roommate. She explained that old people are "set in their ways and that they can't adjust easily to others' ideas." This woman also expressed doubt that she could trust anyone enough to live with her. Her last statement was, "I hope they never put old people together, I would rather go to a nursing home."

Other comments further support this trend. One respondent said, "I want my own apartment," and another said, "I don't want to get in anyone's way." Many people felt old people are "too mean" and "fight too much" to ever live together. Eighty-four percent of the respondents said they preferred to live alone. The majority also said they preferred privacy to companionship. Other comments indicate that few people want to move. One person said, "I waited a long time to get this apartment and I really don't want to give it up." One woman who even seemed willing to roommate added that she "wouldn't want to give up my apartment."

It was also apparent that many people would be willing to live 
with someone if it was only temporary. Could this indicate a slight interest in living with someone without really committing yourself to the relationship? Since the questions were based on suppositions, and many people did appear fearful, possibly some people did not show a willingness to roommate because they were afraid they might be held to such a choice.

\section{CONCLUSIONS}

Based on the data discussed in preceding sections of this report, we feel confident in stating the following conclusions:

1. Most of the people in the study were able to do many things unaided and did not feel alone.

2. Very few of the people in the study were willing to roommate.

3. People who tended to be more independent also tended to be more willing to roommate.

4. Considering all the various factors studied, independence was the most crucial in determining whether a person was willing to roommate.

5. The factors of the study only accounted for a small percentage of a person's willingness to roommate. Other factors must be more important in determining a person's willingness to roommate. 
6. The more independent people in the study tended to be younger, healthier, to have lived in Portland for a relatively shorter length of time and to be more willing to roommate than the less independent people.

7. People who had relatively more education, higher status jobs, and participated in more activities were less lonely than the other people in the study.

8. The most lonely people in the study were men who had never been married or who had been separated from their spouse for a long time.

9. A person's willingness to roommate was not affected by his feeling of being alone.

10. People in the study who had once been married and who had recently been separated from their spouses were the most willing to roommate.

11. Aspects of roommating which were most appealing to the people of the study were: (a) sharing a bathroom, (b) helping a homeless elderly person by sharing one's apartment and, (c) planning meals with another person.

\section{LIMITATIONS OF THE FINDINGS}

Certain limitations of this study must also be kept in mind when discussing the significance of the research findings. The effects of 
the sample selection process must be considered in analyzing the data. First, the actual method of sampling eliminated certain types of people. In order to respond to the letters of introduction, people must be able to read and understand the letter or have someone explain it. Some of the responses received indicated that people felt they could not participate if they had health problems. It is assumed that those who responded favorably to the letters were the most receptive, and open of all of the people who received letters. Since there was no contact with the 174 people who were sent letters but not interviewed, it is not known what factors were influential in determining which people accepted the invitation to participate in this study.

The sample composition must also be considered. In many ways, the people in the sample were quite similar. This uniformity eliminated a great deal of the opportunity for comparisons. The size of the sample is too small to elicit broad generalizations; therefore, one cannot predict implications for the greater population of elderly. Thus, results of our study should only be applied to the sample of people studied.

The fear factor, which was mentioned in Chapter III must also be evaulated in terms of its effects on those who participated in the study and the degree of depth and openness to which one participated. We feel that much of what certain respondents said was colored by their fear of possible repercussions. 
We also caution that the three major variables of loneliness, independence, and willingness to roommate actually measured feelings. Feelings can be subject to flux and do not necessarily correspond with one's affect and actions.

One further significant limitation of the study is that the variables with which we concerned ourselves, only account for $21 \%$ of the influence on an elderly person's willingness to roommate. Other factors, of which we are not aware, are also influencing a person's willingness to roommate.

These limitations should be kept in mind as cautionary elements when considering the results and implications of the study.

\section{RECOMMENDATIONS}

When reviewing the literature, these researchers found that many authors described elderly people as tending to resist change. This seems to correspond with the findings of this study that the longer one is separated from his spouse, the less likely it is that he will be willing to roommate. Perhaps separation from one's spouse should be seen as a crisis, which renders the subject more amenable to change if intervention occurs soon after the time of crisis. In other words, an elderly person might be more willing to roommate if the opportunity is presented to him soon after he is separated from his spouse. At this time, he will be in a state of flux, looking for ways to adjust to 
his new living arrangment. Once he becomes adjusted to living alone, he is seemingly less open to change. We recommend that further research be done with people who have just recently been separated from their spouses to see if they are more willing to roommate. Since one's degree of independence seems to be most influential in determining one's degree of willingness to roommate, further study should include different aspects of independence and dependence. Such a study would contribute to a better understanding of the relationship between independence and willingness to roommate, and also the significance of both dependency and independence for the aged. A sample for such a study might include both independent and dependent people.

The population used for this study can be described as people who are able to do things unaided. Future research should explore the possibility of roommates for a more dependent population. For example, elderly people who are forced to consider moving to a nursing home could be utilized as a dependent population in order to discover if such people would prefer living with a roommate rather than move to a nursing home.

In a sense, a value judgment has been made that for some people, living with a roommate would be a very satisfactory living arrangement. Such a value judgment is apparent in Chapter I. As a result, the authors recommend research in the form of pilot studies. 
One alternative would be to find ways of increasing a person's degree of independence so that he will become more willing to roommate. Another alternative is to establish some sort of half-way house where people can come together and experience living together before making any commitment.

We recommend that sampling changes also be made in any further research. For example, a sample which is more representative of the total Portland population might be used. Such a sample would have enough variation that significant comparisons could be made.

Since this study discovered only $21 \%$ of the variables affecting willingness to roommate, it would seem expedient to research this area further to find the other variables influencing willingness. If we are ever to determine whether a roommate service would be an effective aid to elderly people, more research must be conducted to identify these other variables and discover how they influence willingness. Other types of innovative living arrangments might also be explored, both through the Housing Authority of Portland and on a mass basis. Perhaps, it would be beneficial to explore the idea of malefemale roommates as the elderly have needs of companionship, sex, love and male-female relationships just as younger people do. We feel they should be given the opportunity to meet these needs in an accepting society. Since it might be discovered that single elderly 
males and single, elderly females would actually advocate the idea of being roommates, we feel research in this a rea would be most interesting.

Other possibilities would include less intense types of living arrangements in which social encounter would still be improved. Such ar rangements might include a dormitory or communal type of living arrangement in which many facilities are shared, but one can also have the privacy of his own room. Common dining rooms might also prove interesting alternatives. In all these areas, further research might prove very rewarding.

\section{SUMMARY}

This chapter has been devoted to discussion of the results of the study in more practical terms. Conclusions and implications are only representative of this sample. Although we were unable to show any significant need for a roommate service, we do feel we were able to reach a better understanding of some of the people in the community. We also feel that this study helped us to better formulate possible areas for further research. We sincerely hope that others will follow in working with the elderly. We found these people extremely fascinating and very worthy of better ways of living. 
I. Books

Arthur, Julietta K. How to Help Older People. Philadelphia: J. B. Lippincott Company, 1954.

Beatty, Ralph P. The Senior Citizen. Illinois: Charles C. Thomas, 1962.

Belcher, John C., "A Consequence of the Is olated Nuclear Family," Journal of Marriage and Family, 29, (August, 1967), pp. 534540 .

Bond, Floyd A., Ray E. Baber, John A. Vieg, Louis B. Perry, Alvin H. Scaff, and Luther J. Lee, J r., Our Needy Aged, New York: Henrey Holt and Company, Inc., 1954.

Boucheron, Pierre. How to Enjoy Life After Sixty. New York:

Archer House, Inc., 1959.

Bromley, D. B. The Psychology of Human Aging. Baltimore: Penguin Books, Inc., 1966.

Carp, Francis. A Future for the Aged. Austin: University of Texas Press, $196 \overline{6 .}$

Carson, John J., and McConnell, John W. Economic Needs of Older People. Baltimore: The Lord Baltimore Press, Inc., 1956.

Cavan, Ruth, Ernest W. Burgess, Robert J. Havighurst, and Hewert Goldhamer, Personal Adjustment in Old Age. Chicago: Science Research Associates, Inc., 1949.

Clark, Margaret, and Anderson, Barbara Gallatin. Culture and Aging: An Anthropologic Study of Older America. Springfield, Illinois: Charles C. Thomas, 1967.

Family Service Association of America. Casework with the Aging. New York: Family Service Association, 1961. 
Gavin, Richard M., and Burger, Robert E. Where They Go to Die. New York: Delacorte Press, 1968.

Hansen, Percy M. Never Too Late to be Young. New York: Frederick Fell, Inc., 1966.

Hazell, Kenneth. Social and Medical Problems of the Elderly. Iondon: Hutchins on Medical Publications, Itd., 1965.

Hoskiss on, J. B. Loneliness, An Explanation, A Cure. New York: The Citadel Press, 1964.

Kaplan, Oscar J. Mental Disorders in Later Life. Stanford: Stanford University Press, 1947.

Konopka, Gisela. Social Group Work: A Helping Process. Englewood Cliffs, N. J.: Prentice Hall, Inc., 1963.

Lang, Gladys Engel. Old Age in America. New York: H. W. Wilson Co., 1961.

Langford, Marilyn. Community Aspects of Housing for the Aged. New York: Cornell University Press, 1962.

Lansing, Albert I., ed. Cowdey's Problems of Aging. 3rd ed. Baltimore: Williams and Wilkins Co., 1952.

Larson, Dorothy Hill, ed. Dialogues on Aging. New York: Teacher's College Press, 1966.

Lawton, George, ed. New Goals for Old Age. New York: Columbia University Press, 1944 .

Leeds, Morton. The Aged, The Social Worker, and The Community. Cleveland: Howard Allen, Inc., 1961.

Lourdas, Bernadette de. Where Somebody Cares. New York: G. P. Putnam's Sons, 1954.

May, Edgar. The Wasted American. Signet Books. New York: The New American Library, 1965.

Miller, Delbert C. Handbook of Research Design and Social Measurements. New York: McKay, 1967. 
Moss, Bertram B., M. D. Caring for the Aged. New York: Doubleday and Company, Inc., 1966.

Moustakas, ClarkE. Loneliness. Detroit: Prentice Hall, Inc., 1961.

Neugarten, Bernice L., ed. Middle Age and Aging. Chicago: The University of Chicago Press, 1968.

University of Oregon School of Community Service and Public Affairs. Readings in Gerontology. Eugene: University of Oregon Press, 1969.

Pfeiffer, Eric; Verwoerdt, Adriaan; and Wang, Hsich-Shan. Archives of General Psychiatry. 19, December, 1968.

Reichard, Suzanne; Peterson, Paul; and Livson, Florine. Aging and Personality: A Study of Eighty-Seven Older Men. New York: Wiley, 1962 .

Rich, Thomas A., and Gilmore, Alden S. Basic Concepts of Aging. Tampa: University of South Florida, July, 1969.

Riley, Matilda White, and Foner, Ann. Aging and Society. Vol. 1, New York: Russel Sage Foundation, 1968.

Rose, Arnold M., and Peterson, Warren A., ed. Older People and Their Social World. Philadelphia: F. A. Davis Company, 1965.

Rosow, Irving. Social Integration of the Aged. New York: Free Press, $196 \overline{7 .}$

Shenfield, B. E. Social Policies For Old Age. London: Routledge and Kegan Paul Ltd., 1957.

Shock, Nathan W., ed. Aging, Some Social and Biological Agpects. Washington, D. C.: American Association for the Advancement of Science, 1960.

Soule, George. Longer Life. New York: The Viking Press, 1958.

Thomason, O. Bruce, ed. Potentialities for Later Living. Report of the Southern Conference on Gerontology. Gainesville, Florida: University of Florida Press, 1968. 
Tibbets, Clark, and Donahue, Wilma. Aging in the Modern World. Ann Arbor: The University of Michigan Press, 1957.

, and Orbach, Harold. Aging and the Economy. Ann Arbor: The University of Michigan Press, 1963.

Townsend, Peter. The Family Life of Old People: An Inquiry in East London. London: Routledge and Kegan Paul, 1961.

Tunstall, Jeremy. Old and Alone: A Sociological Study of Old People. London: Routledge and Kegan Paul, 1966.

Wolf, Kurt. The Biological, Sociological and Psychological Aspects of Aging. Springfield, Illinois: Charles C. Thomas, Publisher, 1959 .

Wright, Clarence. Successful Retirement: Plan It Now. Washington, D. C.: Kiplinger Washington Editors Inc., 1964.

Youmans, Grant E., ed. Older Rural Americans, Lexington: University of Kentucky Press, 1967. 


\section{Articles}

"Advice to Women Alone." Modern Maturity, XI (August-September, 1969), pp. 30-31.

"Are You Eating Properly?" Modern Maturity, XI (August-September, 1969), pp. 67-68.

Bixby, Lenore E. "Income of People Aged 65 and Older: Overview from 1968 Survey of the Aged." Social Security Bulletin, XXXIII (Apri1, 1970) pp. 3-35.

Brickfield, Cyril. "Independence vs. Over-Protection." Modern Maturity, XI, (February-March, 1968), p. 39.

Brine, Ruth. "The Old in the Country of the Young." Time Magazine, Vol. 96, (August 3, 1970) pp. 49-54.

Carp, Francis. "Research Studies on the Aged." Welfare in Review, V, (May, 1967), pp. 14-20.

"Correlates of High Morale in Community-Based Aged." Geriatric Focus, Vol. 8, No. 18, (November 1, 1969) pp. 1, 5 .

Council, Pauline E. "Dysfunctional and Alienation in a Small Retirement Village. A Pilot Study." Research Reports in Social Sciences, Vol. 10, No. 1, February, 1967.

"Facts About Senior Sex." Modern Maturity, XI, (August-September, 1968) pp. 15-17.

Genn, Lillian. "Boom in Retirement Marriage." Modern Maturity, XII (February-March, 1970) pp. 12-14.

Geokas, Michael C. and Briley Michael P. "What the Doctor Says." Modern Maturity, XIII (August-September, 1970) pp. 13-14.

"How to Eat Alone." Modern Maturity, XI (October-November, 1968) p. 56.

Joast, Merloo, "Some Psychological Problems of the Aged Patient." New York State Journal of Medicine, Vol. 58, (December, 1958). pp. $3810-3814$. 
Ledgerwood, Ian. "Report on Retirement 'Cities'." Modern Maturity, XII, (August-September, 1969), pp. 21-23.

Lowenthal, Marjorie F. "Social Isolation and Mental Illness in Old Age." American Sociological Review, Vol. 29 (February, 1964), Pp. $54-70$.

"Martin Testifies on Nutrition Needs of Aging." Aging (OctoberNovember, 1969). pp. $12-13$.

Nash, Bernard E. "Improving the Quality of Life." Modern Maturity, XIII (August-September, 1970), p. 58.

. "our No. 1 Priority." Modern Maturity, XIII (AugustSeptember, 1970) p. 4-5.

"New Housing Developments for the Older Citizens Must Make Allowances for Cultural Differences." Geriatric Focus, Vol. 9, (February, 1970).

O'Dell, Betty Young, "Heading off the Problems of the Loner." Today's Health, Vol. 44 (August, 1966), pp. 46-49.

Orshansky, Mollie. "Counting the Poor." Social Security Bulletin, XXVIII, (January, 1965), PP. 3-30.

Orshansky, Mollie. "Who's Who Among the Poor." Soclal Security Bulletin, XXVIII, (July, 1965), pp. 3-33.

"Our Members Write." Modern Maturity, XI, (February-March, 1968), pp. 63-65.

Randall, Ollie. "The Old Person in the Family." New Goals for Old Age. Edited by George Lawton. New York: Columbia University Press, 1944.

Schluderberg, George W. "Retirement is a Graduation." Modern Maturity, XII, (August-September, 1969) p. 4.

Shanas, Ethel. "A Note on Restriction of Life Space: Attitudes of Age Cohorts." Journal of Health and Social Behavior, IX, (March, 1968), pp. 86-91. 
Sherman, Susan; Mangum, Wiley; Dodds, Susan; Walkley, Rosebelle P.; and Wilner, Daniel. "Psychological Effects of Retirement Housing." The Gerontologist, VIII, (Autumn, 1968), pp. 170176.

Smith, Myrna. "How About Mobile Home Living?" Modern Maturity, XIII, (August-September, 1970), pp. 18-22.

Townsend, Peter. "Isolation, Loneliness, and the Hold on Life." Man Alone. Edited by Eric and Mary Josephson. New York: Dell Publishing Company, Inc., 1962.

, "The Family of Three Generations." Presented at the International Social Science Research Seminar in Gerontology, Marbaryd, Sweden, 1963. 
III. Reports and Public Documents

Blenker, Margaret. "The Normal Dependencies of Aging." Paper presented at the Symposium on. Dependency held during the annual meeting of the Gerontological Society, Denver, Colorado, November 2, 1968.

Carp, Francis, ed. The Retirement Process. Bethesda, Md: U. S. Department of Health, Education and Welfare, Bethesda, 1966.

Chrown, Sheila, and Riegal, K. F. ed. Psychological Functioning in the Normal Aging and Senile Adult. Report of an International Colloquium held at Semmering (Austria), June 23-25 (1966), Basil, New York: Karger, 1968.

Council on Social Work Education. Report of the Seminar on Aging. Toward a Better Understanding of the Aging. Council on Social Work Education, New York: 1958.

Eppley, David B. , OAA Recipients in 1965: Health Conditions and Health Services. Social and Rehabilitation Service National Center for Social Statistics Report OAA-5 (65), Washington, D.C. U. S. Government Printing Office, 1969

Howery, Victor. "Preparation for Independent Living." Rehabilitation of the Aging: A New Role of Usefulness. Portland, 1960.

Institute on Rehabilitation of the Aging. Report of the Institute. Rehabilitation of the Aging: A New Role of Usefulness. Portland, 1960.

International Association of Gerontology. Report of the Association. Old Age in the Modern World. London: E. \& S. Livingstone Itd. , 1955.

Meld, Sophia K. "The Open Door Policy as a Method of Helping Lone Aged Persons." Unpublished report on an FSAA Project on Aging, Jewish Family and Child Services, Seattle, 1964.

National Council on Aging. Annual Report of the Council of Economic Advisors. Background Facts on the Income Position of Older Persons. Washington, D. C.: U. S. Government Printing Office. October 5, 1964. 
Occupational Outlook Handbook, 1966-1967. The Bureau of Labor Statistics of the U. S. Department of Labor, Washington, D. C., U. S. Government Printing Office, 1966.

Office of Economic Opportunity. Programs for Older Persons Fact Sheet. Washington, D. C.: U. S. Government Printing Office, 1968 .

Olsen, Roger. Private interview held at the Portland Community Council. Portland, Oregon, February 5, 1971.

Oregon State Council on Aging. Oregon State Factual Report to the White House Conference on Aging. Eugene, Oregon: Oregon State Council on Aging, 1960.

Oyler, Robert. "The Effect of Health on Disengagement and Morale: An Examination of Conflicting Research Findings," Sociological Abstracts, "Abstracts of Papers Presented at the 1969 Annual Meeting of the Rural Sociological Society," suppl. 4, XVII, (August, 1969), p. 47.

President's Council on Aging. The Older American. Washington, D. C.: U. S. Government Printing Office, 1963.

United States Congress, House. Committee on Ways and Means. Family Assistance Act of 1970. 91 st Cong., 2nd sess., Washington, D. C.: U. S. Government Printing Office, 1970.

United States Department of Commerce. Bureau of the Census. General Population Characteristics Report, January, 1971, Pubn. No. PC (V2)-1.

- Bureau of the Census. General Population Characteristics Report, January, 1971, Pubn. No, PC (V2)-39.

United States Department of Health, Education and Welfare. United States Office of Aging. Facts on Aging. No. 1, January, 1963.

- Bureau of Family Services. Foster Family Care for the Aged. Washington, D. C.: U. S. Government Printing Office, 1965.

- Patterns of Living and Housing of Middle-Aged and Older People. Washington, D. C.: U. S. Government Printing Office, 1965. 
- Surveys and Research Corporation. Guide for State Surveys on Aging. Washington, D. C.: U. S. Government Printing Office, 1968.

- Prologue to the 1971 White House Conference on Aging. Older Americans Speak to the Nation. Washington, D. C.: U. S. Government Printing Office, May, 1970.

- Action for Older Americans. Washington, D. C.: U. S. Government Printing Office, 1964.

Workshop for Protective Services of Older Adults. Proceedings of a Conference. Portland: Friendly House, Inc., 1967. 
APPENDICES 


\section{APPENDIX A}

Introductory Letters

Portland State University

School of Social Work

September 10, 1970

Dear

We, Marvin Clifford and Jo Ann Welander, are working with Dr. Martha Ozawa to learn more about the living and housing problems of the elderly. We hope you can help us learn more about these problems.

Please give us the opportunity to chat with you. We feel only you, and other elderly people like you, can help us to better understand the needs and problems of your generation. By giving us the opportunity to chat with you, you will be helping us so that we may make recommendations for improvements in housing for the aged.

Please fill in the enclosed postcard by simply writing in the time you are usually home after each day. For example, if you are home from 9:00 in the morning until 3:00 in the afternoon every Monday and Friday, your card should look like this:

$$
\begin{array}{ll}
\text { Monday 9:00 a.m. }-3: 00 \text { p. m. Friday 9:00 a.m. }-3: 00 \text { p.m. } \\
\text { Tuesday } \\
\text { Wednesday } & \text { Saturday } \\
& \text { Sunday }
\end{array}
$$

Thursday

Next sign the card and fill in your return address. Then drop the postcard in a mailbox.

It is very important that we speak with you because we feel that no one knows more about the problems of the elderly than you, a senior citizen. 
Thank you very much. We hope to meet you very soon.

Sincerely yours,

Marvin Clifford

Jo Ann Welander 


\author{
Portland State University \\ School of Social Work \\ October 28, 1970
}

\title{
Dear
}

Last month we sent you a letter asking you if we could come chat with you. Since we have not heard from you as yet, we have decided to write to you again to remind you of our project.

We, Marvin Clifford and JoAnn Welander, are working towards our Master's Degrees in Social Work at Portland State University. As part of our education we are trying to learn more about elderly people in Portland. Through chatting with you and other senior citizens, we hope to learn more about your generation.

As part of our education we are required to complete a thesis or research project. The housing authority has assisted us by letting us see their list of all people sixty who live in public housing. We in turn, wrote letters to each eighth person on the list, in hopes that we might chat with these people. Please help us in our project. We want to know your opinion and to learn more about you.

Please fill in the enclosed postcard by writing in the time you are usually home in the blank following each day. For example, if you are home from 9:00 in the morning until 3:00 in the afternoon every Monday, Wednesday and Friday, your card should look like this:

\begin{tabular}{|c|c|c|c|}
\hline Monday & $9: 00 \mathrm{am}-3: 00 \mathrm{pm}$ & Friday & $9: 00 \mathrm{am}-3: 00 \mathrm{pm}$ \\
\hline Tuesday & & Saturday & \\
\hline $\begin{array}{l}\text { Wednesday } \\
\text { Thursday }\end{array}$ & $9: 00 \mathrm{am}-3: 00 \mathrm{pm}$ & Sunday & \\
\hline
\end{tabular}

Next sign the card and fill in your return address. Then drop the postcard in the mailbox.

Thank you very much. We hope to meet very soon.

Sincerely yours,

Marvin Clifford

JoAnn Welander 


\section{APPENDIX B}

\section{QUESTIONNAIRE}

Here are some things that quite a few people over 65 have difficulty in doing without help. Do you or would you have difficulty in doing the following?

\begin{tabular}{cll} 
A & \multicolumn{1}{c}{ B } & \multicolumn{1}{c}{ C } \\
No & Can do it alone & Can't Do \\
difficulty & but with diffi- & It At All \\
& culty. & Without \\
& & Help.
\end{tabular}

1. Going out of doors on own.

2. Going up or down stairs on your own.

3: Getting about the house on your own.

4. Getting in and out of bed.

5. Washing or bathing your self.

6. Dressing yourself and putting on your shoes.

7. Going grocery shopping.

8. Doing housecleaning.

9. Cooking.

10. Driving a car.

11. Doing your washing. 
A

B

C

No Cando it alone Can't Do difficulty but with diffi- It At All culty.

Without

Help.

12. Shaving or personal

grooming.

13. Handling your financial matters.

14. Taking advantage of community facilities.

TOTAL

15. When you are going someplace that is not within walking distance from your home, do you:

A. Drive your own car?

B. Usually take a cab or bus?

C. Ask friends or relatives to take you?

16. Do you receive some of your income from relatives or friends or a social service agency?

A. None $-1 / 3 r d$

B. $1 / 3-2 / 3 \mathrm{rds}$

C. More than $2 / 3 \mathrm{rds}$

17. When you are sick, do you usually have others around to help you or check in on you?

A. Have someone a round all the time.

B. Have someone check in occasionally.

C. Don't need others to help me; I can take care of myself. 
18. Suppose you broke your hip and had to be assisted by someone for several months. Which of the following would most likely be your reaction to having to be assisted in doing things?

A. I would find it hard to accept help.

B. It was something that couldn't be helped so I can't do anything about it.

C. I would enjoy being waited on.

19. If for some reason you were having difficulty in your living arrangement and institutional living was suggested as an alternative to your present living arrangement, how would you decide what to do?

A. I would make the choice myself without any other people interfering in my decision.

B. I would consider the suggestions of others in making my decision.

C. I would want someone else to make the decision for me.

20. How active are you politically?

A. Very active (i.e. campaigning, soliciting, and/or running for office.)

B. Usually vote at most elections.

C. Not at all active. (i.e., I usually don't even vote.)

21. Are you presently employed?

A. Full time.

B. Part time.

C. Not at all.

22. At what age did you retire?

A. 64 or younger

B. $65-69$

C. 70 or older 
23. Did you chose to retire?

A. Yes

B. No

24. If you chose to retire, why did you do so? (Main reason)

A. There were so many things I wanted to do. (i.e., hunt, fish, and other hobbies.)

B. I had enough money saved to do so.

C. My job was becoming more than I could handle.

25. If you were forced to retire, why was it so?

A. It was company policy

B. I don't know.

C. I was no longer able to adequately handle my job. (Health reasons)

26. What type of living arrangement would you choose if you had a choice?

A. Independent living arrangement (own house)

B. Independent living arrangement in a rented house or a partment

C. Modified independent living arrangements. (With common services for laundry, dining, housekeeping, etc.)

27. Do you feel less alone now than when you were younger?

A. Agree

B. Uncertain

C. Disagree

28. Do you feel that other people really don't care about what happens to you?

A. Agree

B. Uncertain

C. Disagree 
29: Do you feel your family is concerned about you?
A. Agree
B. Uncertain
C. Disagree

30. Society doesn't really care about you because you a re old?
A. Agree
B. Uncertain
C. Disagree

31. There's little use writing to public officials because often they aren't really interested in the problems of the ordinary elderly person.
A. Agree
B. Uncertain
C. Disagree

32. These days an elderly person doesn't really know who he can count on.
A. Agree
B. Uncertain
C. Disagree

33. In spite of what some people say, the life of the ordinary elderly person is worse, not better.
A. Agree
B. Uncertain
C. Disagree

34. Society today is only concerned with the young.
A. Agree
B. Uncertain
C. Disagree

35. Please respond to the following statement. "I feel very much that I belong here."
A. Agree
B. Uncertain
C. Disagree 
36. Do you feel free to invite your neighbors or friends over for tea or coffee?
A. Often
B. Sometimes
C. Never

37. Do you feel that you have friendly talks with your neighbors or friends fairly often?
A. Yes, frequently

B. Sometimes

C. Not at all

38. Do you feel that you don't really have a very close friend with whom you can share your feelings.

A. Yes

B. Undecided

C. No

39. When you are with other people do you feel they really enjoy having you a round?

A. Yes, I usually feel this way.

B. Sometimes

C. No, I never feel this way.

40. Do you wish you were with people more often?

A. Yes, I feel I'm not with others enough.

B. Not necessarily

C. I am with others enough.

41. Do you think you could find a good friend in this community?

A. Very true

B. Undecided

C. Definitely untrue

42. Local concerns deal fairly and squarely with everyone.

A. Very true.

B. It depends.

C. Definitely. 
43. A lot of people you know think they are too nice for you.

A. Very true

B. It depends

C. Definitely untrue

44. Almost everyone is polite and courteous to you.

A. Very true

B. It depends

C. Definitely untrue

45. Do you prefer to live alone?

A. I wouldn't think of living any other way.

B. It really doesn't make any difference.

C. I would much rather live with others.

46. Would you mind sharing your bathroom with another elderly person?

A. Yes, I would mind.

B. Uncertain

C. I wouldn't mind.

47. Would you be willing to share expenses for rent for an apartment with another elderly person of the same sex?

A. I would be willing

B. Uncertain

C. I wouldn't be willing.

- Would you be willing to live with the following persons?

48. Iiving with relatives:

— Willing _ I don't know _ _ _ Not willing

49. Iiving with friends:

Willing I I I don't know ___ Not willing

50. Iiving with some I don't know:

willing

I don't know

Not willing 
51. Suppose you had to share your furniture with another elderly person what would be your reaction to this?

A. I would dislike this.

B. It doesn't make any difference.

C. I would enjoy sharing my furniture.

52. Suppose you had to move out of your present living a r rangement because of an eviction notice. Would you be willing to move in with another elderly pers on of the same sex who was someone you knew and someone you would feel compatible with?

A. I would be willing.

B. Only if it were a temporary arrangement.

C. I would not be willing to do so.

53. Suppose you lived alone in an apartment would you appreciate the opportunity of being able to be by yourself?

A. Yes, this is something I need very much.

B. It doesn't really matter.

C. No, I would rather have others a round me.

54. Suppose someone from a social service agency came to you and stated he knew some elderly people that needed a place to live. Would you be willing to have one of these elderly persons move in with you?

A. I would be willing to try it.

B. I would have to think about it.

C. I would not consider it.

55. If you could have either privacy or companionship in your living arrangement, which would you prefer?
A. Privacy
B. It doesn't really matter
C. Compan- ionship

56. Suppose another elderly pers on you knew invited you to move in with him. What would be your reaction to the idea of living with this person?

A. I would be excited about this.

B. I would think about it.

C. I wouldn't like living with another person. 
57. Would you consider moving if the Housing Authority let you live with another elderly person without increasing your rent? (The two of you together would pay as much as you are now paying alone.)
A. Yes
B. Uncertain
C. No

58. Suppose you have a friend come to stay with you from out of town who is rather sloppy, i.e. doesn't hang up his clothes, doesn't rinse out the bathtub, or leaves his dirty dishes without washing them. How would you feel about inviting your friend to come and stay again?

A. I would enjoy cleaning up after him as a small price to pay for his companionship.

B. I'm undecided if I would invite him again.

C. I would never invite him again.

59. Would you find it difficult to plan your meals with another person?

A. Difficult

B. I could tolerate it.

C. Not difficult

60. Sex:

Male

Female

61. How old are you?

A. 60-69

B. $70-79$

C. 80 or

over

62. What is your present marital status?
A. Single
B. Married
C. Divorced
D. Separated
E. Widowed

63. If you are divorced, separated, or widowed, how long have you been so? (Most recent occurrence)
A. $1-5$ years
B. $5-10$ years
C. 10 years
or more

64. How many times have you seen your doctor in the past year?
A. $0-3$ times
B. 4-7 times
C. 8 or more
times

65. How much medication do you take?
A. one pill a day or less
B. 2 to 5 pills a day
C. 6 or more pills a day 
66. How many weeks were you in the hospital the past five years?
A. None
B. 1-5 weeks
C. Six or more

67. Do you have any of the following conditions or diseases?

A. Arthritis or rheumatism

B. High blood pressure

C. Heart trouble

D. Other (specify)

E. None

68. What is your religion?
A. Protestant
B. Catholic
C. Other

69. What is your race?
A. Caucasian
B. Negro
C. Oriental

70. How long have you lived in Portland?

A. Less than 3 years

B. $3-6$ years

C. More than 6 years

71. If you live alone, how long have you lived alone?

A. Less than three years

B. $3-6$ years

C. More than six years

72. What is your present annual income?

A. Less than $\$ 1,900$ per year

B. $\$ 1,000$ to $\$ 5,000$ per year

C. $\$ 5,000$ or more

73. How many years of formal education have you completed?
A. 8 or less
B. $9-12$ years
C. Beyond 12

74. What was your occupation before you retired?
A. Professional
B. Business
C. Clerical or
D. Skilled
E. Unskilled
Sales 
75. In which of the following activities do you participate and how often do you participate each month?

$$
\text { Activity Participation How often }
$$

A. Church services

B. Church social clubs

C. Agency sponsored clubs

D. Clubs with friends or neighbors

E. Volunteer work

F. Babysitting

G. Visiting friends

H. Visiting relatives

I. Other

TOTAL
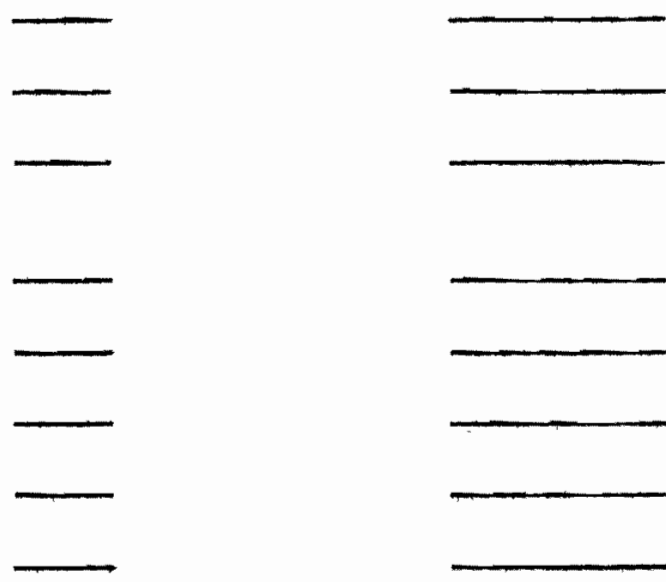

76. Which of the following have you done within the past month? Have you done them alone or with someone? How many days per week?

Activity

A. Walking

B. Shopping

C. Listening to the radio

D. Watching TV

E. Reading

F. Sewing or knitting

G. Golfing

H. Fishing

I. Other
Alone With someone How Many Days Per Week

TOTAL 
77. How often do you eat your meals with other people?

A. Once or more per day

B. Once or more per week

C. Only on special occasions 
APPENDIX C

ANSWER SHEET (I)

A B C

A B C

1.

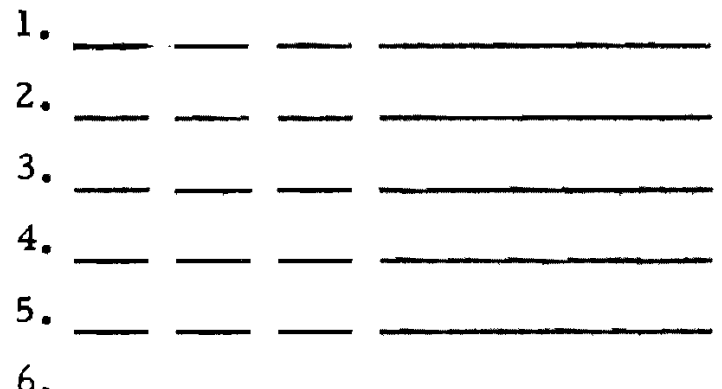

7.

8.

9.

10.

11.

12.

13.

14.

15.

16.

17.

18.

19.

20.

21.

22.

23.

24.
25. 26.

27.

28.

29.

30.

31.

32.

33.

34.

35 .

36.

37.

38.

39.

40.

41.

42.

43.

44.

45.

46.

47.

48. 
A $B$ C

49

50.

51 .

52 .

53.

54.

55.

56.

57.

$\begin{array}{lllllllll}\text { A } & \text { B } & \text { C } & \text { D } & \text { E } & \text { F } & \text { G } & \text { H } & \text { I }\end{array}$

60.

61.

62.

63.

64.

65.

66.

67.

68 .

69.

70 .

71 .

72 .

73.

74.

75 .

76.

77.
A B C

58.

59.

\section{A B C}

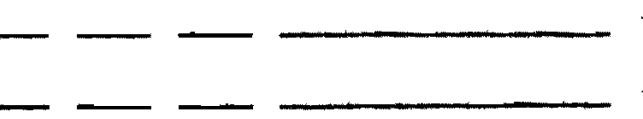


APPENDIX D

\section{LEGEND FOR SCORING}

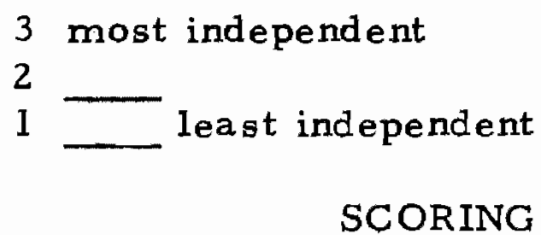

A

B

INDEPENDENCE

\begin{tabular}{|c|c|c|c|}
\hline & A & B & C \\
\hline 1. & 3 & 2 & 1 \\
\hline 2. & 3 & 2 & 1 \\
\hline 3. & 3 & 2 & 1 \\
\hline 4. & 3 & 2 & 1 \\
\hline 5 . & 3 & 2 & 1 \\
\hline 6. & 3 & 2 & 1 \\
\hline 7. & 3 & 2 & 1 \\
\hline 8. & 3 & 2 & 1 \\
\hline 9. & 3 & 2 & 1 \\
\hline 10. & 3 & 2 & 1 \\
\hline 11. & 3 & 2 & 1 \\
\hline 12. & 3 & 2 & 1 \\
\hline 13. & 3 & 2 & 1 \\
\hline 14. & 3 & 2 & 1 \\
\hline 1. & -14. TOTAL & & \\
\hline
\end{tabular}




$$
\text { 15. } \begin{aligned}
3 & =\mathrm{A} \\
2 & =\mathrm{B} \\
3 & =\mathrm{C}
\end{aligned}
$$

16. 3 2 1

17. 3 2 1

18. 3

2

1

19. 3

2

1

20. 3

2

1

21. 3

2

1

22. 3

2

1
23. No answer

24. 3

2

1

25. 3

only answer 24 or 25 2

1

26. 3

2

1
Add Score 1 - 26

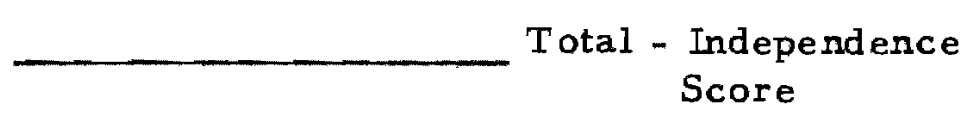


FEELING OF BEING ALONE SCORE

27. 1

2

3

28. 3

2

1

29. 1

2

3

30. 3

2

1

31. 3

2

1

32. 3

2

1

33. 3

2

1

34. 3

2

1

35. 1

2

3
36. 1

2

3

37. 1

2

3

38. 3

2

1

39. 1

2

3

40. 3

2

1

41. 1

2

3

42. 1

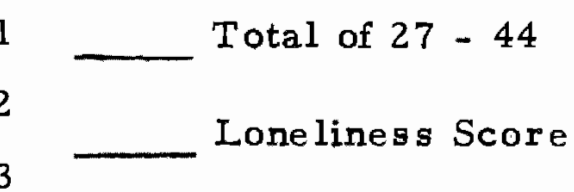

43. 3

2

1

44. 1

2

3 


\section{WILIINGNESS TO ROOMMATE}

\section{Least Willing \\ 2 \\ 3 Most Willing}

45. 1

2

3

46. 1

2

3

47. 3

2

1

48. 3

2

1

49. 3

2

1

50. 3

2

1

51. 1

2

3

52. 3

2

1
53. 1

2

3

54. 3

2

1

55. 1

2

3

56. 3

2

1

57. 3

2

1

58. 3

2

1

59. 1

2

3

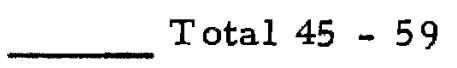

Willingness to Roommate Score 
CONTROLS

Sex

60. A. 1
B. 2
A1.
A. 1
B. 2
C. 3

68. 1

3

69. 1

A. 1

B. 2

C. 3

D. 4

E. 5

63. A. 1

B. 2

C. 3

64. A. 3

B. 2

C. 1

65. A. 3

B. 2

C. 1

66. A. 3

B. 2

C. 1

70. 1

3

71. 1

2

3

72. 1

2

3

73. 1

2

3

74. 5

4

3

2

1

67. A. $3=$ no checks

B. 2 = one check

C. $1=$ two checks or more

Add $72-74$

$64-67$ TOTAI

$$
\begin{aligned}
& 9-11=\text { Upper class }=3 \\
& 6-8=\text { Middle class }=2 \\
& 3-5=\text { Lower class }=1
\end{aligned}
$$

10-12 Excellent health $=3$

7-9 Average health $=2$

4-6 Poor health $=1$ 
75. Total number of activities

Number of times per month

76. Number of activities done alone

Number of activities done with someone times 2 Number of activities per week

77. 3

2

1

Add scores $75-77$

90 and above $=$ very active $=3$

$89-30=$ average $=2$

29 or less = inactive=1 


\section{APPENDIX E}

\section{SCORING CHANGES}

1. Question 23, 2425 omitted from independence.

2. Sex changed from 1,2 to -1 for males, 1 for females.

3. Race was discarded.

4. Religion was changed to 2 categories: Christian

Other

5. Marital status changed to: $1=$ never married

-1 = once married

6. Health questions 64-67 were scored individually, i. e. each question was listed independently of the others. 
APPENDIX $\mathbf{F}$

TABLE XVI

SIMPLE INTERCORRELA TION MATRIX

\begin{tabular}{|c|c|c|c|c|c|c|c|c|c|c|c|c|c|c|}
\hline & 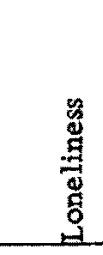 & 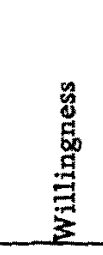 & × & $\stackrel{\infty}{\infty}$ & 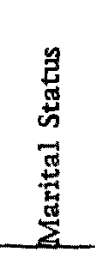 & 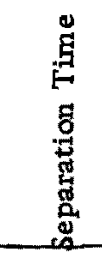 & $\begin{array}{l}\text { 吾 } \\
\text { J }\end{array}$ & 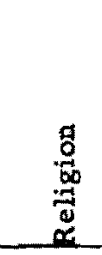 & 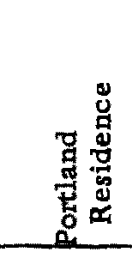 & 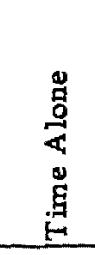 & 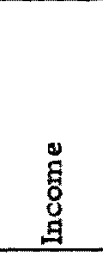 & 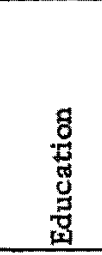 & 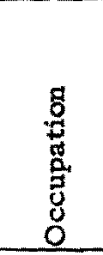 & 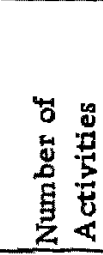 \\
\hline Independence & -.06 & .27 & .01 & -.25 & .00 & .03 & .23 & .04 & -.21 & .06 & -.09 & .09 & .06 & .14 \\
\hline Loneliness & & -.17 & .31 & -.04 & .33 & .31 & -.02 & -.11 & -.09 & .09 & .00 & -.25 & -.27 & -.24 \\
\hline Willingness & & & -.11 & .07 & -.22 & -.26 & .09 & .10 & -.11 & -.18 & -.01 & -.02 & .00 & .04 \\
\hline Sex & & & & -.19 & .31 & .31 & -.05 & -.22 & -.12 & .04 & -.32 & .10 & -.04 & -.10 \\
\hline Age & & & & & .01 & .04 & .05 & .02 & -.07 & .09 & -.07 & .03 & -.04 & -.11 \\
\hline Marital Status & & & & & & .95 & -.06 & -.13 & .09 & .15 & -.09 & .03 & -.10 & -.21 \\
\hline Separation Time & & & & & & & -.10 & -.17 & .12 & .34 & -.07 & -.01 & -.10 &.- .31 \\
\hline Health & & & & & & & & -.02 & -.19 & -.08 & .05 & -09 & -.17 & .04 \\
\hline Religion & & & & & & & & & -.11 & -.01 & .05 & -.11 & -.18 & .09 \\
\hline Portland Residen & & & & & & & & & & .00 & .06 & .02 & -.03 &.,- 10 \\
\hline Time Alone & & & & & & & & & & & -.08 & -.09 & .15 & -.25 \\
\hline Income & & & & & & & & & & & & .22 & .05 & .03 \\
\hline Education & & & & & & & & & & & & & .58 & .09 \\
\hline Occupation & & & & & & & & & & & & & & .13 \\
\hline
\end{tabular}

